
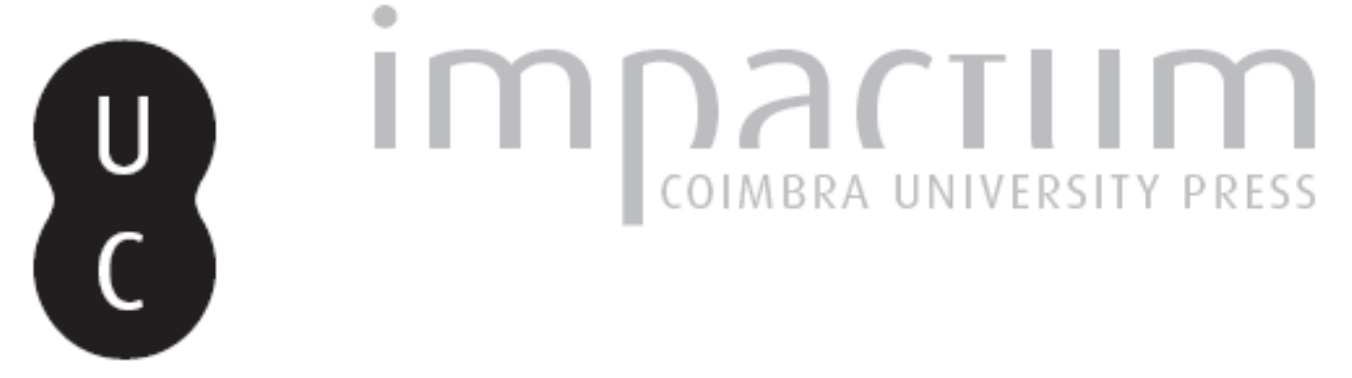

\title{
Causas de incêndios florestais em Portugal continental: análise estatística da investigação efetuada no último quindénio (1996 a 2010)
}

\begin{tabular}{ll} 
Autor(es): & $\begin{array}{l}\text { Lourenço, Luciano; Fernandes, Sofia; Bento-Gonçalves, António; Castro, } \\
\text { Ana; Nunes, Adélia; Vieira, António }\end{array}$ \\
$\begin{array}{ll}\text { Publicado por: } & \text { Faculdade de Letras da Universidade de Coimbra, Departamento de } \\
\text { Geografia }\end{array}$ \\
$\begin{array}{ll}\text { URL } \\
\text { persistente: }\end{array}$ & URI:http://hdl.handle.net/10316.2/30199 \\
DOI: & DOI:http://dx.doi.org/10.14195/0871-1623_31_6 \\
Accessed : & 26-Apr-2023 11:49:29 \\
\hline
\end{tabular}

A navegação consulta e descarregamento dos títulos inseridos nas Bibliotecas Digitais UC Digitalis, UC Pombalina e UC Impactum, pressupõem a aceitação plena e sem reservas dos Termos e Condições de Uso destas Bibliotecas Digitais, disponíveis em https://digitalis.uc.pt/pt-pt/termos.

Conforme exposto nos referidos Termos e Condições de Uso, o descarregamento de títulos de acesso restrito requer uma licença válida de autorização devendo o utilizador aceder ao(s) documento(s) a partir de um endereço de IP da instituição detentora da supramencionada licença.

Ao utilizador é apenas permitido o descarregamento para uso pessoal, pelo que o emprego do(s) título(s) descarregado(s) para outro fim, designadamente comercial, carece de autorização do respetivo autor ou editor da obra.

Na medida em que todas as obras da UC Digitalis se encontram protegidas pelo Código do Direito de Autor e Direitos Conexos e demais legislação aplicável, toda a cópia, parcial ou total, deste documento, nos casos em que é legalmente admitida, deverá conter ou fazer-se acompanhar por este aviso.
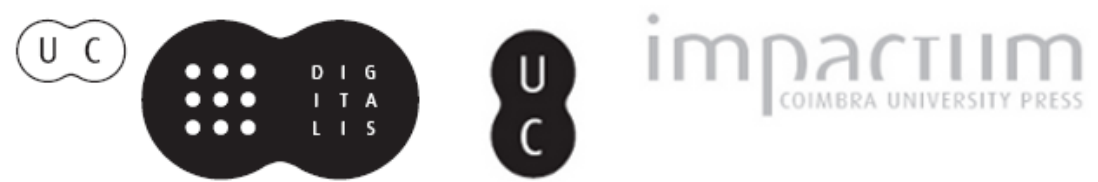


\title{
Causas de incêndios florestais em Portugal continental. Análise estatística da investigação efetuada no último quindénio (1996 a 2010)
}

\author{
Luciano Lourenço \\ Núcleo de Investigação Científica de Incêndios Florestais (NICIF) e Departamento de Geografia, Faculdade de Letras da Universidade de Coimbra.
}

\section{Sofia Fernandes}

Núcleo de Investigação Científica de Incêndios Florestais (NICIF). Faculdade de Letras da Universidade de Coimbra.

\section{António Bento-Gonçalves}

Núcleo de Investigação Científica de Incêndios Florestais (NICIF) e Departamento de Geografia. Universidade do Minho.

\section{Ana Castro}

Núcleo de Investigação Científica de Incêndios Florestais (NICIF) e Departamento de Matemática. Instituto Superior de Engenharia do Porto.

\section{Adélia Nunes}

Núcleo de Investigação Científica de Incêndios Florestais (NICIF) e Departamento de Geografia. Faculdade de Letras da Universidade de Coimbra.

\section{António Vieira}

Núcleo de Investigação Científica de Incêndios Florestais (NICIF) e Departamento de Geografia. Universidade do Minho.

\section{Resumo:}

Ao longo dos últimos anos, Portugal não tem conseguido travar os incêndios florestais, tanto no que diz respeito número de ocorrências como no que se refere à dimensão das áreas ardidas, sobretudo durante o período estival, quando dominam temperaturas elevadas e a dessecação dos combustíveis gera um ambiente propício à propagação dos incêndios, cuja ignição, em mais de $90 \%$ dos casos, tem origem em atos humanos, negligentes e intencionais.

Com o objetivo de melhor compreender a origem destes incêndios florestais, o presente estudo visa analisar as causas responsáveis pela ignição dos incêndios florestais em Portugal e acompanhar o modo como elas foram evoluindo, quer ao longo do tempo, quer em termos da sua distribuição espacial, no período compreendido entre 1996 e 2010.

Palavras-chave: Incêndios florestais. Ocorrências. Causalidade. Área ardida.

\section{Résumé:}

Les causes des incendies de forêt au Portugal. L'analyse statistique de la recherche menée au cours des quinze dernières années (1996-2010)

Ces dernières années, le Portugal n'a pas réussi à freiner les incendies de forêt, sois en termes de nombre d'occurrences, sois en termes de taille des aires brûlées, surtout pendant l'été lorsque les températures sont élevées et la sécheresse des combustibles génère un environnement propice à la propagation des incendies dont ignition, dans plus de $90 \%$ des cas, a son origine dans des actes humains, par négligence ou intentionnellement.

Afin de mieux comprendre l'origine des incendies de forêt, cette étude envisage d'analyser les causes responsables de l'ignition des feux de forêt au Portugal et comprendre la façon dont ils ont évolué temporellement et spatialement, pendant la période de 1996 à 2010.

Mots-clés: Feux de forêt. Occurrences. Causalité. Aire brûlée.

\section{Abstract:}

Causes of forest fires in Portugal. Statistical analysis of the investigation performed over the last fifteen years (1996-2010)

Over the last years, Portugal has not been able to stop the forest fires, both in respect to the number of occurrences and in the size of burnt areas, especially during the summer season, when the high temperatures and the drying 


\begin{abstract}
fuel generates an environment favorable to the spread of fires, whose ignition has its origin in human acts, negligent and intentional, in more than $90 \%$ of the cases.

In order to better understand the origin of the forest fires, this study aims to analyze the causes responsible for its ignition in Portugal and monitor how they have progressed, both over the time and in terms of spatial distribution, between the period of 1996 and 2010.
\end{abstract}

Keywords: Forest fires. Occurrences. Causality. Burnt area. Portugal.

\section{Introdução}

De modo geral, os incêndios florestais têm vindo a causar cada vez maior impacte em diversas regiões do globo onde, no período correspondente à estação seca ou em anos secos, a vegetação se encontra num adiantado processo de dessecação. Nestas condições, os incêndios florestais marcam e alteram profundamente a paisagem por onde se desenvolvem e alastram.

Esta combustão descontrolada afeta, de modo expressivo, as diferentes componentes dos ecossistemas naturais onde incide, designadamente a vegetação e o solo, provocando na sua passagem efeitos de carácter imediato, ausência temporária de vegetação e domínio da cinza, bem como outros, de efeito mais tardio, nomeadamente a degradação da qualidade dos solos e o desenvolvimento de processos de erosão, além de que pode pôr, ainda, em causa tanto a vida, como os haveres do ser humano.

Como é bem conhecido, de entre os vários países do mundo que sofrem de forma sistemática com os incêndios florestais, Portugal é um espaço geográfico que, proporcionalmente, se evidencia entre eles, não só pelo número de ocorrências, mas também pela dimensão das áreas queimadas, para o que muito contribuiu a existência de alguns anos particularmente complexos, mas, em regra, a problemática persiste, sendo de difícil resolução.

A fim de tentar minimizá-la, várias têm sido as iniciativas legislativas, tais como o Decreto-Regulamen$\operatorname{tar} 55 / 81$ ou os Decretos-Lei 156/2004 e 124/2006, para mencionar, apenas, alguns dos muitos documentos legais que tratam do assunto, mas, apesar dessas iniciativas, com importantes contributos para uma melhor prevenção e organização do dispositivo operacional de combate, ainda não se encontrou solução para o problema.

Este estudo enquadra-se nessa perspetiva de melhoria contínua e pretende ir um pouco mais além, efetuando uma análise exaustiva, à escala nacional, das causas de incêndio florestal (categoria, grupo e subtipo), no período compreendido entre 1996 e 2010. O principal objetivo prende-se com a necessidade de, com base na investigação efetuada, conhecer as causas mais significativas que estão na origem dos incêndios florestais em Portugal e como têm evoluído, ao longo dos anos, por forma a dar uma visão exata da verdadeira dimensão deste problema.

Ainda que não sejam considerados uma causa direta, neste estudo entendemos dever mencionar também os reacendimentos, apesar de consistirem no "reativamento de um incêndio, depois de este ter sido considerado extinto. A fonte de calor é proveniente do incêndio inicial. Um reacendimento é considerado parte integrante do incêndio principal (a primeira ignição observada não depende de qualquer outra área percorrida por um incêndio)" (CARvalho e Lopes, 2001: 7), mas, do ponto de vista operacional, é importante perceber porque existem.

De facto, os reacendimentos ocorrerem por fracasso da fase de rescaldo do incêndio, apesar desta constituir parte integrante do combate e ser uma das suas fases mais importantes (LouREnço et al., 2001: 98). Com efeito, condições meteorológicas favoráveis podem contribuir para a "reativação" de incêndios que não foram totalmente extintos e, por conseguinte, tiveram como fonte de ignição primeira, uma das seis possíveis categorias de causa: Uso do Fogo, Acidental, Estrutural, Incendiarismo, Natural e Indeterminada.

Embora não sejam objeto de análise aturada, importa conhecer o fenómeno, para melhor se poder prevenir. Na realidade, ocorre um número relativamente elevado de situações que permitem a reativação dos incêndios após estes terem sido considerados extintos, sendo alguns deles responsáveis por uma área ardida significativa.

\section{Metodologia}

Numa primeira fase, procedeu-se à uniformização da base de dados, disponibilizada pela Autoridade Florestal Nacional ${ }^{1}$ (http://www.afn.min-agricultura.pt/portal/ dudf/estatisticas), tarefa que se verificou ser indispensável, devido à existência de pequenas incongruências identificadas e que poderiam criar dificuldades ao nível da análise da informação, numa posterior fase de tratamento, correspondente à da aplicação de técnicas estatísticas para análise das causas dos incêndios florestais ocorridos em Portugal continental, entre 1996 e 2010.

A metodologia adotada passou pela uniformização de todos os ficheiros relativos a incêndios florestais, dis- 
poníveis na página web da Autoridade Florestal Nacional, referentes ao período compreendido entre 1996 e 2010.

Para esse efeito, todos os incêndios que apresentam a respetiva causa classificada em duas categorias distintas, foram trabalhados por forma a que uma delas fosse eliminada, de acordo com os critérios que se estabeleceram, conforme se exemplifica com as classificações indicadas a seguir:

- 121 - Natural

I. 0 código 121 faz referência ao subgrupo Limpeza do solo agrícola (121), do grupo das Queimadas (12), no Uso do fogo (1).

II. Por sua vez, a classificação de Natural remete para o código 5 - Causas naturais.

Ora, no contexto dos incêndios florestais, a limpeza do solo agrícola implica a queima controlada de combustíveis agrícolas, tanto de forma extensiva (queimada) como de modo intensivo (queima de sobrantes), pelo que a sua passagem a incêndio não decorre de uma origem natural, mas antes de atos negligente ou intencionais, de natureza antrópica, pelo que se classificou como causa 121.

De igual modo, todas as situações que apresentam uma categoria de causa Natural e outra que não seja do subgrupo 51 Raio, foram tratadas de igual modo.

- 31 - Intencional

I. 0 código 31 indica o grupo referente a Caça e Vida Selvagem (31), da categoria de causas Estruturais (3).

II. Em contrapartida, a causa Intencional remete para a categoria 4, alusiva ao Incendiarismo.

Como as causas estruturais (Uso do Fogo, Acidentais, e Estruturais) se referem a atos negligentes e, ao mesmo tempo, se apresenta a causa Intencional, que atualmente é reconhecida por Incendiarismo, optou-se por classificá-la como Incendiarismo, excluindo a causa Estrutural, uma vez que ao haver uma ação intencional, $o$ ato negligente perde sentido.

As situações em que é indicada a causa "intencional", mas onde foi atribuído um código não referente a esta categoria, foram tratadas do mesmo modo, o que significa que a origem do incêndio passou a ser considerada como Incendiarismo.

- 6 - Negligente

I. 0 código 6 refere-se às causas indeterminadas em que, por falta de prova material, pessoal, ou por lacunas na informação, não foi possível definir a origem exata do incêndio.

II. Por sua vez, a causa Negligente remete para uma situação onde houve negligência por parte de quem executou a atividade.
Nestes casos, considerou-se que todos os registos que apresentassem o código 6 , referente às causas indeterminadas, seriam diretamente aceites, excluindo o segundo elemento.

Com efeito, o simples facto de se atribuir esta categoria a uma causa, deixa subentender que a informação disponível não é suficiente para definir, objetivamente, a origem do incêndio. Todavia, em função de alguns elementos, poderá admitir-se um possível ato negligente, que não foi possível confirmar.

- 23 - Desconhecida

I. 0 código 23 indica a situação de que a causa da origem do incêndio provém de outras causas acidentais (23), que vão além das identificadas, na categoria 2 (causas acidentais).

II. Por seu lado, o termo Desconhecida remete para uma causa cuja origem não foi determinada. Sendo assim, todas estas situações foram classificadas com a categoria de causas Indeterminadas.

- 412 - Negligente

I. 0 código 412 remete para o subgrupo - Brincadeiras de crianças (412), do grupo Inimputável (41) pertencente a categoria 4 - Incendiarismo.

II. Por outro lado, Negligente remete para uma situação onde houve negligência por parte de quem executou a atividade.

Neste caso temos a oposição de duas categorias - Negligência vs Incendiarismo, o que traz alguma dificuldade ao nível da escolha da causa do incêndio, tendo-se optado pelo código 412, que assume o incêndio como Incendiarismo, independentemente de se tratar de negligência ou dolo.

- 131 - Negligente

I. O código 131 remete para um incêndio que teve origem num ato negligente do Uso do Fogo para o Lançamento de foguetes (13), onde foram tomadas medidas preventivas (131).

Nestes casos em que o código atribuído pertence a uma das três categorias - Uso de Fogo, Acidentais e Estruturais -, e houver referência à causa "negligência", decidiu-se que, nestas situações, a causa do incêndio florestal será a constante do código (categoria, grupo e subgrupo), visto que, um incêndio pode deflagrar por situações negligentes, por exemplo quando do uso do fogo na queima de lixo em zona de núcleos habitacionais permanentes, mas também por razões acidentais ou, até, mesmo até por circunstâncias estruturais.

Além destas situações, também houve necessidade de esclarecer as situações das causas de incêndio mencionadas como ato Negligente, mas sem especifica- 
ção de qualquer código, sobretudo de incêndios constantes da antiga classificação.

Nestas condições, atendendo a que, na nova classificação, se podem reportar três categorias: 1 .Uso do Fogo, 2. Acidentais e 3.Estruturais, fez-se uma distribuição do efetivo existente em cada concelho e em cada um dos anos, proporcional ao número médio anual de efetivos de cada uma dessas três categorias dos anos em que essa informação está detalhada.

Estes foram os critérios utilizados para uniformizar uma informação que, na origem, estava classificada de modo diferente, o que dificultava a análise comparativa dos dados existentes.

Uma vez concluída esta retificação, foi então possível avançar para um primeiro tratamento estatístico das causas responsáveis pela deflagração dos incêndios florestais no território continental, do qual se dá conta neste artigo.

Assim, durante este período de 15 anos, registaram-se 387.963 ocorrências das quais 26466 não foram devidamente extintas e por isso se reacenderam. Como, em $84 \%$ destas, a causa apontada para a ocorrência foi o próprio reacendimento do incêndio, se bem que, por não ser uma verdadeira causa de incêndio, não deveria ser mencionada como tal, tanto mais que só em $16 \%$ das ocorrências que reacenderam (4243 reacendimentos) foi identificada a causa inicial.

Deste modo, optou-se por fazer também uma referência aos reacendimentos, os quais, apesar de não serem uma causa direta de incêndios, apresentam um valor médio anual bastante elevado $(1764,4$, precisamente). Este valor de reacendimentos, aliado à significativa área ardida deles resultante, traduz eventuais fragilidades ao nível do rescaldo efetuado durante a primeira intervenção pelo que deverão merecer uma séria análise por parte dos responsáveis pelo combate, para que possam vir a ser corrigidas as debilidades existentes.

\section{Causalidade de incêndios florestais em Portugal continental}

A análise estatística das ocorrências dos incêndios florestais, nos últimos 15 anos, permite mostrar não só a distribuição do número das ocorrências ao longo desses anos, como se irá observar, tanto em termos da sua evolução temporal como da respetiva distribuição espacial, mas também, de entre elas, evidenciar as que foram investigadas, no que diz respeito à sua origem, ou seja, à determinação das causas que as provocaram.

\subsection{Evolução temporal}

Em termos da evolução anual das ocorrências no período considerado, ou seja, entre 1996 e 2010, verificou-se um número médio de 25.864 ocorrências por ano. Francamente abaixo deste valor médio, situaramse alguns dos últimos anos, designadamente, 2004, 2006, 2007, 2008 e 2010, bem como, anteriormente, o ano de 1997. Ainda que esta tendência possa parecer traduzir uma certa diminuição do número de ocorrências nos últimos anos, esta redução parece-nos mais dependente das condições meteorológicas do que em resultado de efetivas medidas de prevenção.

Com efeito, o ano de 2009, com condições meteorológicas um pouco mais severas, semelhantes às de anos anteriores, logo ultrapassou claramente aquele valor médio, situando-se próximo de anos anteriores, com valores ligeiramente acima de 25000 ocorrências. São disso exemplo os anos de 1996, 1999, 2001, 2002 e 2003, ou ainda os anos de 1998, 2000 e 2005, em que os valores foram significativamente superiores, aproximandose ou ultrapassando 35.000 ocorrências, valores efetivamente anormais, mas enquadrados por uma conjuntura em que as condições meteorológicas foram francamente favoráveis à ignição de incêndios florestais.

0 ano de 2005 foi, na verdade, caraterizado por condições meteorológicas foram extremamente favoráveis à eclosão, razão porque nesse ano se atingiu o valor máximo, com mais de 35.000 ignições (Figura 1).

No que respeita à origem destas ocorrências, a investigação das respetivas causas tem variado ao longo dos anos, pelo que entendemos considerar três situações distintas. A primeira delas corresponde aos quatro anos iniciais, de 1996 a 1999 (Figura 2), que se inicia com uma razoável percentagem média de ocorrências investigadas (aproximadamente $16 \%$ no primeiro ano), mantendo-se muito semelhante nos anos seguintes, o que parece revelar que a investigação terá decorrido toda ela com elevados padrões de qualidade.

Seguiu-se-lhe um período de transição, de 2000 a 2005, que se caracterizou por uma acentuada queda na investigação das causas de incêndios, a qual se situou sempre em valores inferiores a $10 \%$ das ocorrências. Esta situação correspondeu a alterações na organização da Guarda Florestal, que se consumou com a sua integração na GNR. Coincidiu, também, com um período que se revelou particularmente complicado em termos de incêndios florestais, com o ano de 2005 a registar o maior número de ocorrências desde que há registos e o ano de 2003 a deter o recorde da maior área ardida

${ }^{2}$ Fogacho - Incêndio cuja área ardida é inferior a 1 hectare (CARVALHO e LOPES, 2001: 7). 


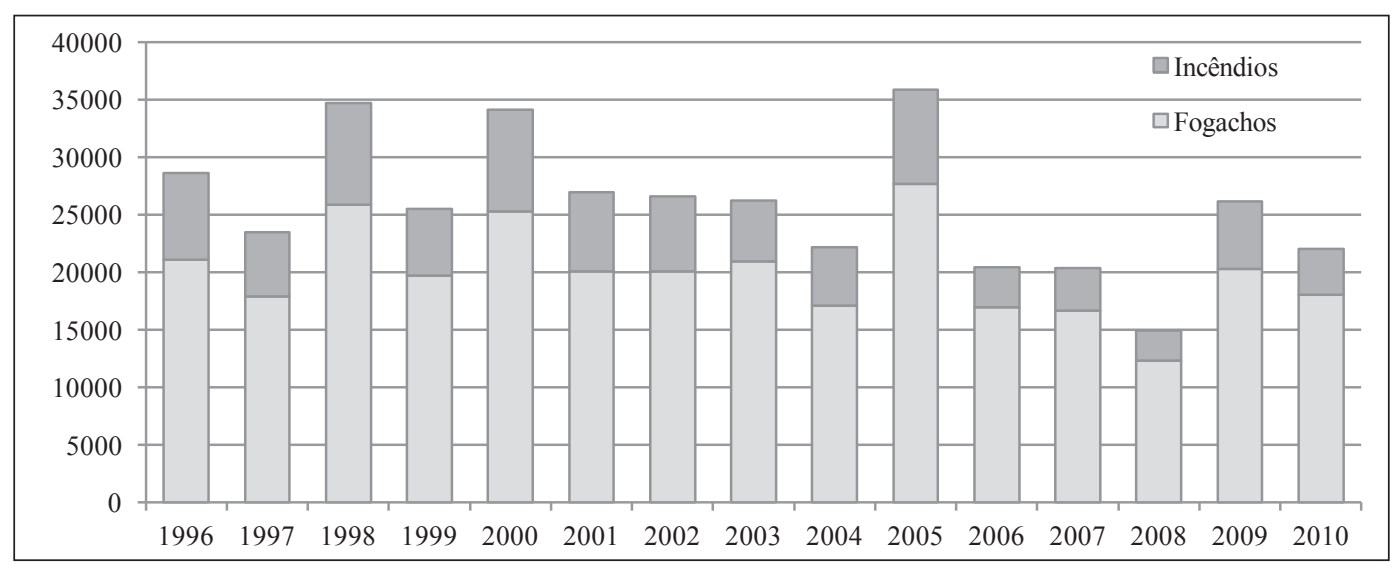

Figura 1

Distribuição anual do número de ocorrências de fogachos ${ }^{1}$ e incêndios florestais, em Portugal continental, entre 1996 e 2010.

Fonte: Dados estatísticos da Autoridade Florestal Nacional.

(Figura 1). Uma das previsíveis reações a estes factos deveria traduzir-se, obviamente e como seria desejável, no aumento do número de ocorrências investigadas nos anos seguintes, o que veio a verificar-se.

Deste modo, o quinquénio seguinte, começou com o ano de 2006, a superar a barreira dos $10 \%$, tendo-se situado em $12 \%$ de ocorrências investigadas, ano que marcou o início do terceiro e último período e que se traduziu num significativo aumento do número de ocorrências investigadas. Esta situação, vir-se-ia a expandir e consolidar nos anos seguintes, nos quais se verificou um substancial reforço das ocorrências investigadas, as quais, no último ano se cifraram em $61 \%$ de ocorrências investigadas, o que corresponde a uma amostragem muito significativa (Figura 2). Todavia, este substancial aumento do número de investigações efetuadas não se traduziu num melhor conhecimento das causas, uma vez que grande parte destas investigações não foram conclusivas, no que ao apuramento das causas diz respeito, pelo que, como veremos adiante, também neste caso, maior quantidade não significou mais qualidade.

No que diz respeito aos incêndios com causas investigadas e relacionando-os com as áreas ardidas anualmente no período considerado (1996 a 2010), verificou-se que, como seria de esperar, a área ardida resultante de fogachos é pouco expressiva (Figura 3), devido ao facto de qualquer deles corresponder sempre área ardida inferior a 1ha, pelo que a grande maioria da área ardida resulta de incêndios superiores a 1 hectare, salientando-se, em todo

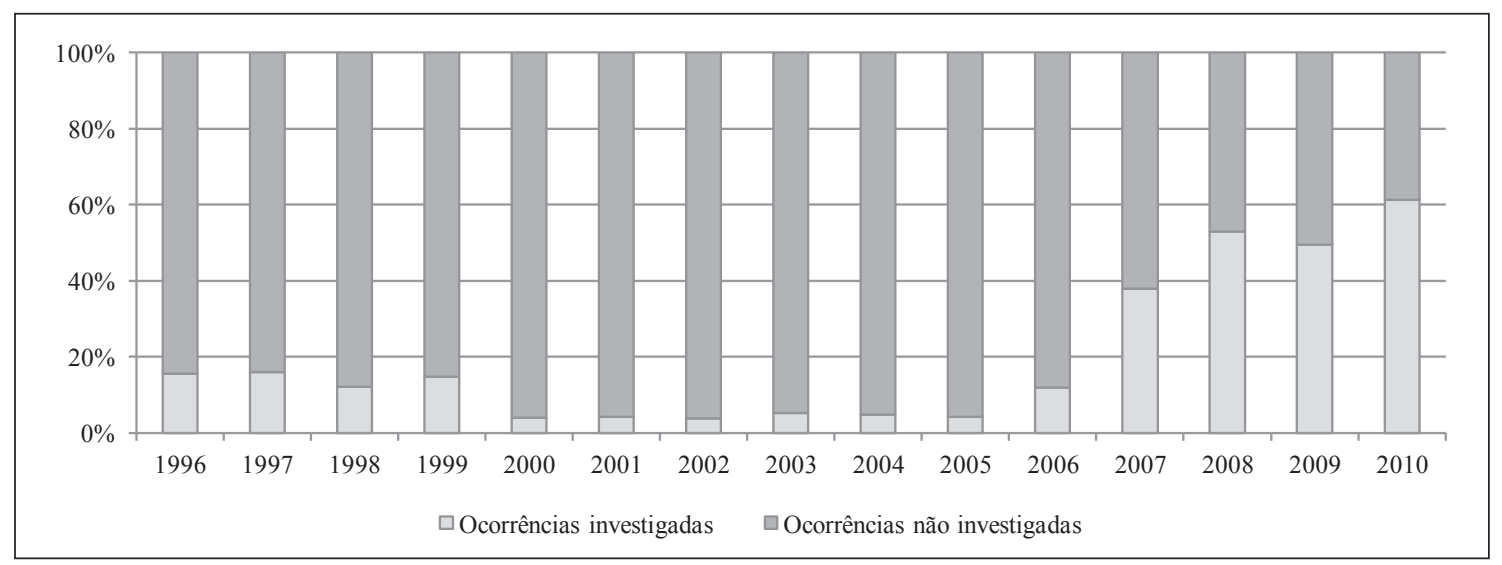

Figura 2

Distribuição anual, em percentagem, das ocorrências de incêndios florestais no território de Portugal continental, em função das causas, investigadas ou não investigadas, entre 1996 e 2010.

Fonte: Dados estatísticos da Autoridade Florestal Nacional. 


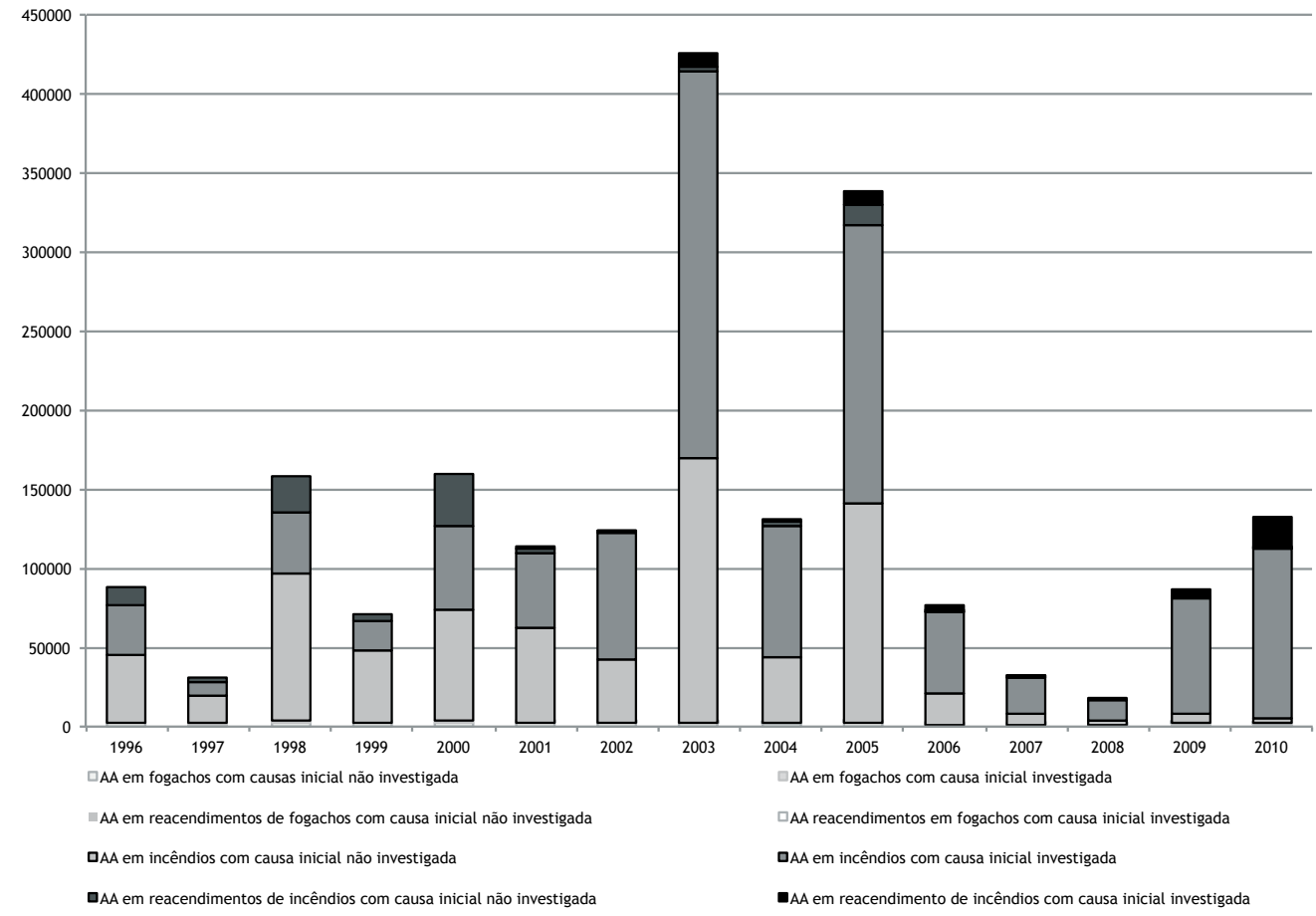

Figura 3

Distribuição anual dos valores da área ardida cujas causas foram investigadas ou não, por categorias de fogachos, incêndios e reacendimentos, no período de 1996 a 2010.

Fonte: Dados estatísticos da Autoridade Florestal Nacional.

o período de análise, os anos de 2003 e 2005, com sendo os que apresentaram maiores valores de área ardida.

Com base nesta análise, parece poder concluir-se que a prioridade na investigação das causas esteve relacionada com a dimensão dos incêndios, ou seja, decorreu da extensão da área ardida (Figura 3). Existem, naturalmente outros critérios, como sejam a presunção de intencionalidade, a proximidade da equipa de investigação, entre outros, pelo que parece não existir aleatoriedade no método de seleção da classificação das ocorrências de incêndios, o que coloca alguns entraves à representatividade das amostras investigadas, no que concerne à extrapolação dos resultados obtidos para as causas investigadas para a plêiade da totalidade dos incêndios.

\subsection{Distribuição espacial}

No que diz respeito à distribuição espacial do número de incêndios florestais investigados, verificou-se que, de um modo geral, não houve proporcionalidade nessa investigação, designadamente entre os distritos em que registaram os maiores valores de ocorrências de incêndios florestais e aqueles em que se observou maior preocupação no apuramento das causas que estiveram na origem desses mesmos incêndios (Figura 4).

Com efeito, nos distritos onde a densidade de ocorrências por $\mathrm{Km}^{2}$ é maior, como é o caso do Porto, onde o valor médio anual é superior a 2 ocorrências por $\mathrm{km}^{2}$, ou de Braga, registam-se das mais baixas percentagens de causas de incêndios investigadas, respetivamente 5 e $12 \%$.

Nos distritos pertencentes à classe seguinte de densidade de ocorrências: Lisboa, Viana do Castelo e Aveiro, observou-se que Lisboa investigou menos de metade da percentagem observada nos outros distritos, ou seja, $8 \%$, contra 22\% de Aveiro e $25 \%$ de Viana do Castelo.

Por sua vez, os distritos com maior percentagem de causas de incêndios investigadas são Coimbra, mais precisamente $39 \%$ e, depois, Viseu e Leiria respetivamente com 32 e $31 \%$, de ocorrências investigadas (Figura 4).

Esta diferenciação permite mostrar que, em Portugal continental, a averiguação das causas dos incêndios florestais é muito desigual, havendo entre os diferentes 


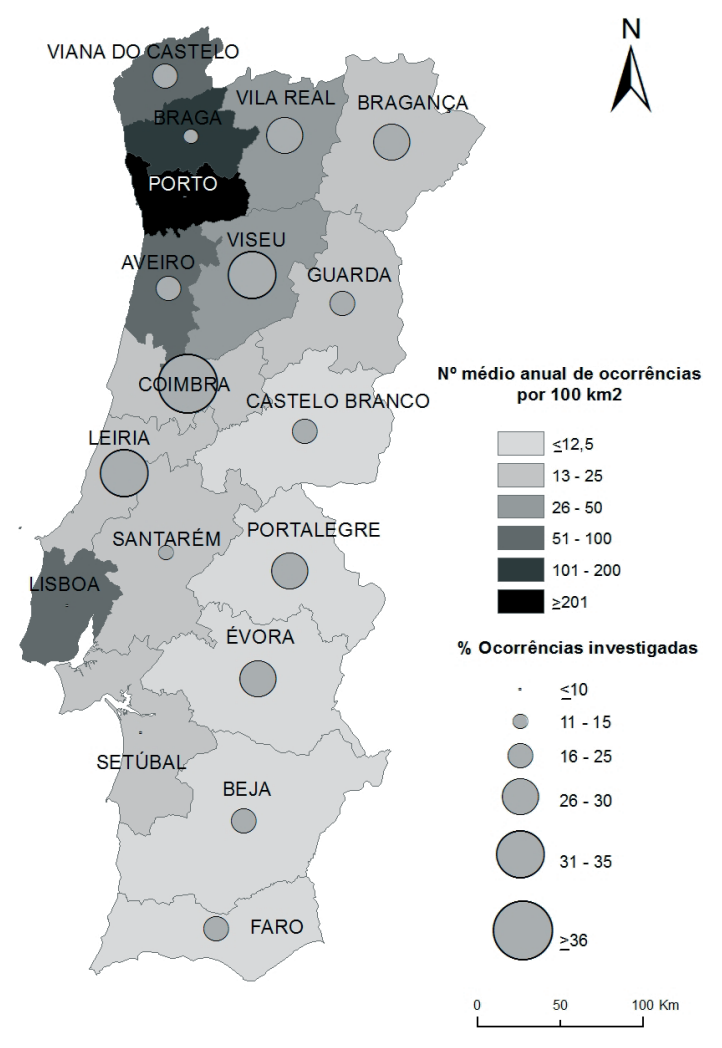

Figura 4

Distribuição espacial do número médio anual de ocorrências por 100 Km², por distritos, e respetiva percentagem de causas de incêndios investigadas.

Fonte: Dados estatísticos da Autoridade Florestal Nacional. distritos um forte contraste na importância que se dá à investigação das causas que originam incêndios florestais.

Em termos absolutos, as diferenças entre o número médio anual de ocorrências nos diferentes distritos também é enorme (Figura 5), com destaque para os do Porto, com uma média anual de 5749, Braga (3419), Lisboa (2425), Viseu (2342), Vila Real (1930), Aveiro (1917), Viana do Castelo (1567) e Guarda (1259). Os restantes situam-se todos abaixo das 1000 ocorrências/ano e, no fundo da tabela, surgem os distritos de Portalegre, com uma média de 100 ocorrências/ano, Beja com 94 e Évora com 75, o que mostra bem a desigual distribuição dos incêndios no território continental (Figura 5).

E se a diferença entre o número de ocorrências é grande entre os vários distritos, maior é ainda a proporcionalidade entre estas e as investigadas em termos das respetivas causas (Figura 5), pelo que, em alguns distritos deveria ser feito um maior esforço com vista a esse apuramento, dada a grande diferença existente entre o número de ocorrências e a percentagem de causas investigadas.

\subsection{Relação entre o número de incêndios investigados e a respetiva área ardida}

Procedendo à análise comparativa dos valores anuais do número de ocorrências investigadas e respetiva área ardida, com os valores anuais das ocorrências de incêndios florestais com causa não investigada e respetiva área ardida (Figura 6), confirma-se a existência de um certo desfasamento entre o número de ocorrên-

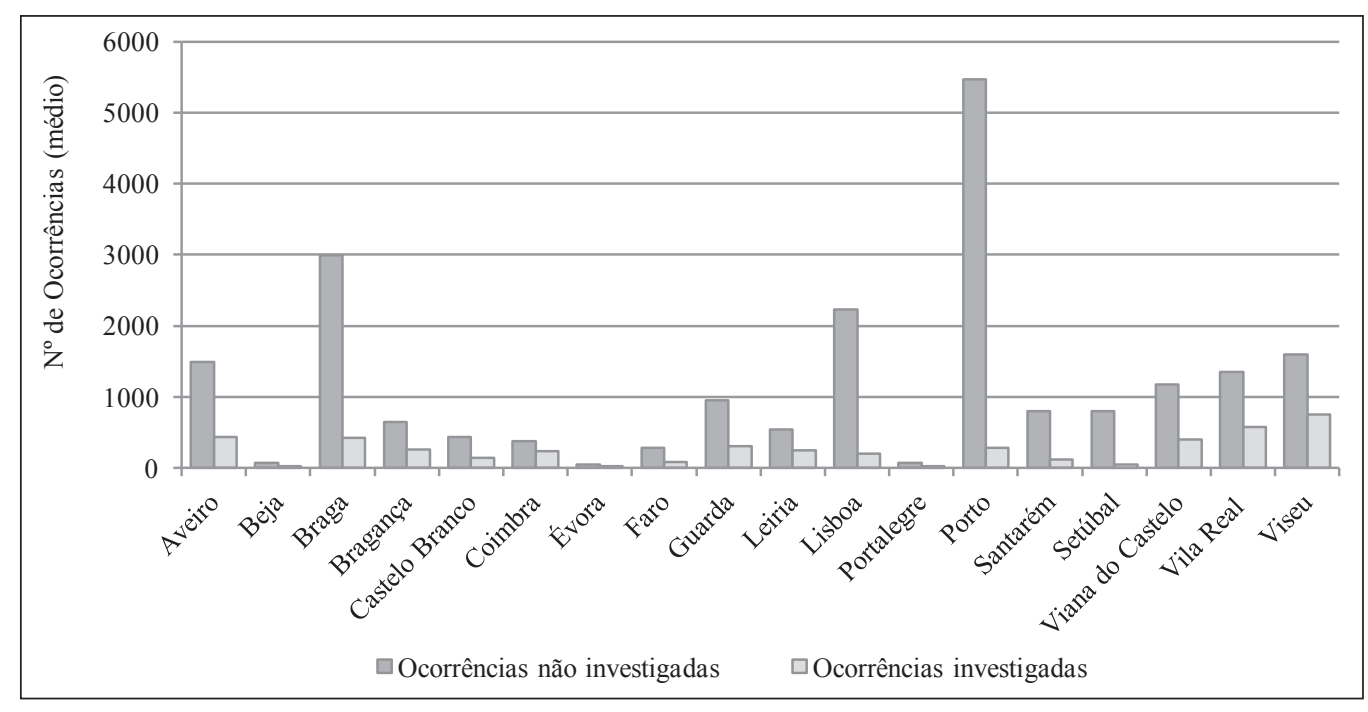

Figura 5

Distribuição do número médio anual de ocorrências de incêndios florestais, investigadas e não investigadas, por distritos, no período compreendido entre 1996 e 2010.

Fonte: Dados estatísticos da Autoridade Florestal Nacional. 
cias com causa investigada e causa não investigada, como se descreveu anteriormente, o que confirma que este tipo de investigação não tem por base um processo de amostragem aleatória.

Por outro lado, observa-se que, até ao ano de 2001, os valores da área ardida dos incêndios investigados relativamente aos não investigados tende a aproximar-se, embora com ligeiras oscilações. Depois, a partir do ano de 2002, há um claro desfasamento entre o valor das áreas correspondentes a incêndios com causa investigada e não investigada, situação que, aliás, se foi acentuando, no decurso do tempo, o que demonstra claramente que a investigação das causas de incêndios não é aleatória e, por conseguinte, que não se podem nem devem extrapolar, para o universo das ocorrências de incêndios florestais, os resultados obtidos com esta investigação das causas.

De facto, esta análise mostra claramente que, no contexto geral, um dos critérios que parece ser privilegiado para a seleção do apuramento das causas de ignição é o da dimensão da área ardida, mormente quando esta foi significativa, como é o caso dos grandes incêndios e que, se do ponto de vista criminal faz todo o sentido, coloca algumas reservas quanto a considerar os resultados assim obtidos como sendo representativos das causas dos incêndios florestais em Portugal.
2. Análise das categorias de causas responsáveis pela ignição dos incêndios florestais em Portugal e respetivos subtipos

A definição e codificação das causas dos incêndios florestais em Portugal é feita, desde há vários anos, tendo vindo a sofrer alguns ajustamentos com vista ao afinamento das classes e subclasses a usar nessa classificação, mudanças que se refletiram no modo de apresentação dos dados resultantes da investigação desenvolvida ao longo desses anos.

\subsection{Categoria de causas}

Entre 1996 e 2000, as causas de ignição eram catalogadas em quatro grandes categorias, não havendo qualquer referência aos subtipos dessas categorias. As causas eram, assim, associadas a dois atos distintos ou, se preferirmos, a dois comportamentos diferentes das pessoas: Negligente e Intencional, aos quais acresciam as causas de ordem Natural, felizmente muito reduzidas, e, ainda, aquelas que, apesar de terem sido investigadas, não foi possível apurar e, por conseguinte, permaneceram como causa Desconhecida.

A partir do ano de 2001, procurou-se atribuir maior precisão à identificação das causas, pelo que as categorias usadas até então foram alteradas. Passaram

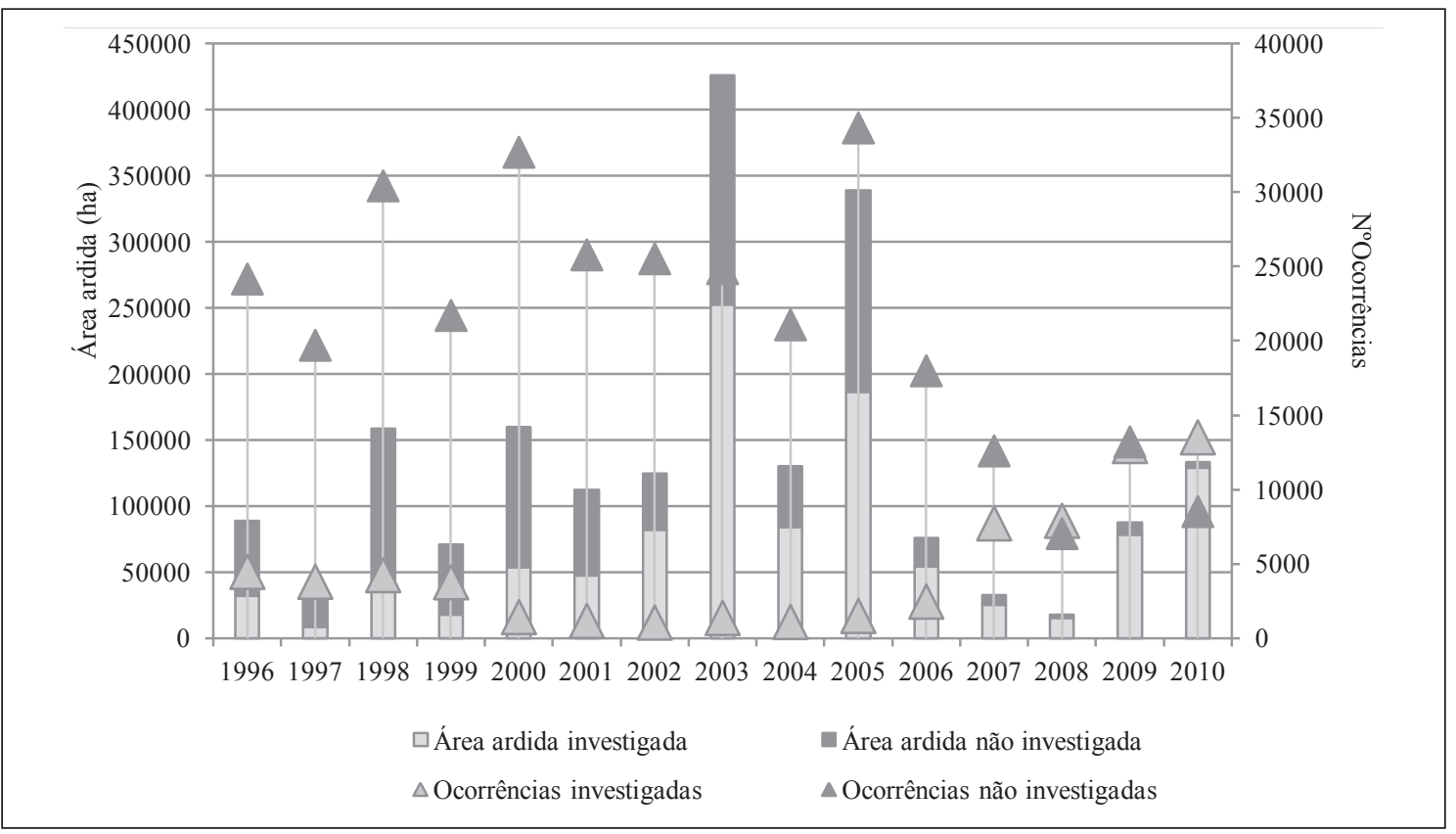

Figura 6

Distribuição anual do número das ocorrências de incêndios florestais em Portugal continental, com causa investigada e não investigada, com as respetivas áreas ardidas, no período compreendido entre 1996 e 2010.

Fonte: Dados estatísticos da Autoridade Florestal Nacional. 
a ser consideradas seis, em vez das quatro anteriores, tendo assumido as seguintes designações: Uso do Fogo, Acidentais, Estruturais, Incendiarismo, Naturais e Indeterminadas.

De um modo muito simples, podemos referir que a antiga denominação negligente foi dividida em três novas categorias de causas (uso do fogo, acidentais $e$ estruturais) na medida em que qualquer uma delas pode resultar de um ato negligente, mas, no entanto, configuram atitudes/comportamentos bem diferentes. Por sua vez, a causa intencional passou a designar-se de incendiarismo, e as causas desconhecidas passaram a denominar-se indeterminadas. As naturais mantiveram a anterior denominação.

Esta alteração das designações foi também acompanhada por uma maior precisão no que aos comportamentos diz respeito, pelo que cada uma destas categorias de causa foi subdividida em subtipos e, dentro de cada um dos subtipos, houve divisão em comportamentos de causa.

No entanto, o nosso estudo apenas incidiu sobre as categorias e os seus subtipos, tendo analisado apenas as seguintes categorias e respetivos subtipos:

- Uso do Fogo

- Queima de Lixo,

- Queimadas,

- Lançamento de foguetes,

- Fogueiras,

- Fumar,

- Apicultura,

- Chaminés;

- Acidentais

- Transportes e comunicações,

- Maquinaria e equipamento,

- Outras causas acidentais;

- Estruturais

- Caça e vida selvagem,

- Uso do solo,

- Defesa contra incêndios,

- Outras causas estruturais;

- Incendiarismo

- Inimputáveis e Imputáveis;

- Naturais

- Raio;

- Indeterminadas

- Indeterminadas

Ainda que, na tabela de codificação e definição das causas de incêndios da Autoridade Florestal Nacional, não seja mencionada a categoria dos reacendimentos, aquilo que se verifica nos relatórios é a inclusão dos reacendimentos como causa, o que nos levou a também os considerar na presente análise, ainda que como elemento secundário de estudo, pois assumem bastante significado no conjunto das causas investigadas.

Por outro lado, o facto dos dados relativos aos subtipos apenas terem sido catalogados a partir de 2001, levou-nos a considerar, para este tipo de análise, apenas os anos de 2001 a 2010.

\subsection{Distribuição das ocorrências por categorias de causa}

Empiricamente, por aquilo que se vê nas notícias e lê nos jornais, existe uma tendência generalizada para se assumir que a principal categoria de causas de incêndios florestais em Portugal, aquela que é mais destacada, corresponde ao Incendiarismo.

Contudo, estatisticamente, entre 1996 e 2010, de todas as ocorrências investigadas no nosso território, a categoria que mais se salientou foi a das causas Indeterminadas. Todavia, as causas Indeterminadas não são uma verdadeira causa, pelo que o Incendiarismo, que aparece em segundo lugar, apenas com cerca de $1 / 3$ do número de ocorrências com causa indeterminada e seguido de muito perto pelo Uso do Fogo com quase igual número de efetivos (Quadro I), é de facto a primeira causa de incêndios em Portugal.

Desde logo, em termos de valores, das 68298 ocorrências investigadas, 34638 foram classificadas como tendo origem Indeterminada, o que revela um grande défice de eficácia no que respeita à averiguação e ao apuramento das causas de ignição dos incêndios florestais em Portugal, uma vez que das causas investigadas, em cerca de $50 \%$ dos casos não foi possível apurar a causa.

Com efeito, tal significa que, na prática, apenas em 7,99\% do total das ocorrências se apurou a respetiva

Quadro I

Distribuição dos valores correspondentes a cada uma das categorias de causas de incêndio florestal em Portugal, entre 1996 e 2010.

\begin{tabular}{|c|c|c|c|}
\hline Ordem & Categoria de causa & $\begin{array}{c}\text { N. }{ }^{\circ} \text { de ocorrências } \\
\text { investigadas }\end{array}$ & Média anual \\
\hline $1^{\circ}$ & Indeterminadas & 34638 & 2309 \\
\hline $2^{\circ}$ & Incendiarismo & 13277 & 885 \\
\hline $3^{\circ}$ & Uso do Fogo & 12992 & 866 \\
\hline $4^{\circ}$ & $\begin{array}{c}\text { Reacendimentos } \\
\text { (com causal inicial } \\
\text { investigada) }\end{array}$ & 4243 & 283 \\
\hline $5^{\circ}$ & Acidentais & 2060 & 137 \\
\hline $6^{\circ}$ & Naturais & 550 & 37 \\
\hline $7^{\circ}$ & Estruturais & 538 & 36 \\
\hline Total de causas investigadas & 68298 & 4553 \\
\hline
\end{tabular}

Fonte: Dados estatísticos da Autoridade Florestal Nacional. 
causa, uma vez que em $8,15 \%$ delas, embora tendo sido investigada, a causa não foi apurada e, em $83,86 \%$ dos casos, nem sequer houve investigação (Figura 7).

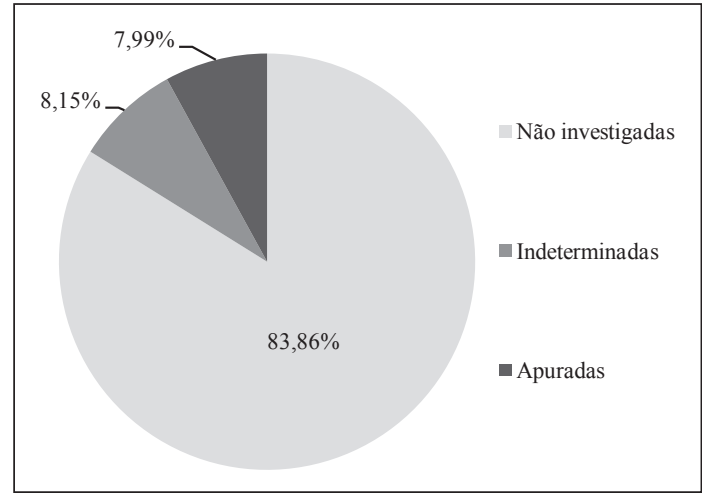

Figura 7

Distribuição dos valores correspondentes às causas não investigadas, indeterminadas e apuradas, entre 1996 e 2010.

Fonte: Dados estatísticos da Autoridade Florestal Nacional.

Em termos médios anuais este valor corresponde a 2309 ocorrências, o que traduz uma média elevada sem apuramento da respetiva causa (Figura 8), o que deveria levar à reflexão sobre os motivos que conduziram à não identificação destas causas, para poderem vir a ser corrigidos e, deste modo, afinar o apuramento das causas.

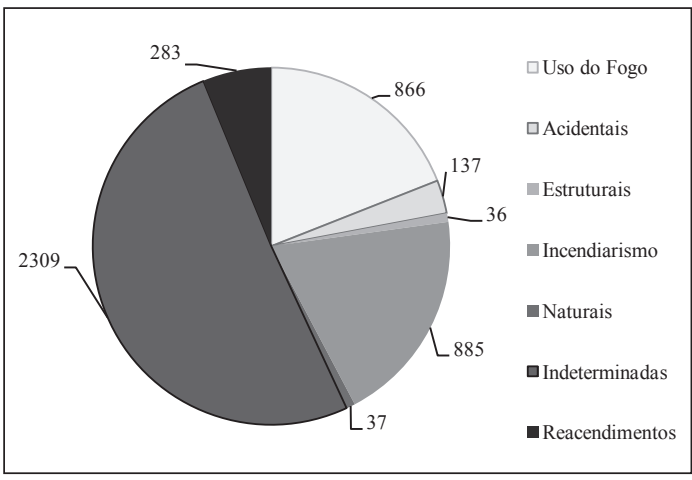

Figura 8

Distribuição do valor médio anual de ocorrências em Portugal, por categorias de causa, entre 1996 e 2010.

Fonte: Dados estatísticos da Autoridade Florestal Nacional.

As razões que poderão contribuir para essa investigação inconclusiva resultam, em primeiro lugar, da falta de recursos humanos e, em segundo lugar, da destruição dos indícios, devido à falta de cuidado dos bombeiros na sua preservação, e ainda, de alguma demora na chegada dos meios de investigação ao local da ocorrência uma vez que "o sucesso da determinação da causa é, por norma, inversamente proporcional ao tempo decorrido entre a hora da eclosão e a do conhecimento dos factos e, depois, entre esta e a do início da inspeção ao local” (Silva, 2001 apud Bento Gonçalves, Lourenço e SILVA, 2007: 82).

De fato, nos dias com elevado número de ocorrências é impossível acorrer a todas elas num curto intervalo de tempo, razão porque algumas só são investigadas passados alguns dias, o que contribui para dificultar o trabalho das equipas. Por outro lado, nem sempre as equipas são suficientemente zelosas e diligentes na busca de indícios ou no seguimento das pistas que poderiam ajudar a determinar as causas do incêndio, razões que concorrem para a existência de tão elevado número de causas que ficam por apurar e, por conseguinte, são classificadas como indeterminadas.

$\mathrm{Na}$ segunda posição surge, como vimos, o Incendiarismo, mas na prática corresponde à primeira causa identificada, com uma média anual de 885 ocorrências (Figura 8), posicionamento que, em parte, traduz uma certa ineficácia da investigação das causas, se tivermos em conta que é a mais explorada pelos meios de comunicação social. De facto, esta categoria corresponde às causas de incêndio que indiciam uma origem criminosa, mas que raramente chega ou se comprova em tribunal, pelo que este valor aparece, assim, muito empolado. Esta categoria está associada a situações de irresponsabilidade e dolo, muitas vezes aliadas a interesses económicos, desejo de vingança, vandalismo ou simples práticas pirómanas, o que contribui para a dificuldade do apuramento deste tipo de causa.

Com menor impacto na comunicação social, mas necessitando de uma atenção particular, destacam-se as categorias de causas associadas aos atos de incúria e desleixo por ação humana, nomeadamente, no Uso do fogo negligente que, com uma média anual de 866 ocorrências, está muito próxima do Incendiarismo.

Considerando que a amostragem não é aleatória, e que todos os incêndios com suspeita de origem criminosa têm prioridade na investigação, estamos fortemente inclinados a aceitar que esta causa possa ser aquela que, na realidade, maior número de ocorrências provoca.

Algumas das situações em que o uso do fogo tem provocado incêndios florestais estão relacionadas com o processo de confeção de alimentos, em locais contíguos a espaços propícios à propagação, ou no processo de renovação de pastagens em que, muitas vezes, se iniciam queimadas sem qualquer vigilância, algumas das 
quais acabam por se transformar num verdadeiro pesadelo para os habitantes, quando volvem incêndios de grandes proporções.

Uma das consequências lógicas do resultado desta investigação deveria traduzir-se em sensibilização de públicos-alvo específicos, designadamente dos causadores de incêndios negligentes, para que os originados por esta causa pudessem ser evitados ou, pelo menos, drasticamente reduzidos.

Surpreendentemente, em quarto lugar, com valor superior ao somatório dos incêndios florestais resultantes de atos acidentais, estruturais e naturais, que se posicionam nos lugares seguintes, surgem os Reacendimentos que, em média, rondaram 283 por ano, os quais, como referimos anteriormente, bem poderiam ter sido evitados e provavelmente estarão subavaliados.

Apesar de não serem uma causa direta e, por conseguinte, não entrarem na contabilidade da codificação das causas, não devem deixar de ser considerados numa análise objetiva das causas de incêndio florestal. Com efeito, se não tivesse existido uma causa inicial, não poderia existir reacendimento, pelo que, do ponto de vista da codificação, é a primeira que deve ser considerada.

Todavia, se os incêndios iniciais tivessem ficado devidamente extintos, não teria havido reacendimentos. Por conseguinte, se eles existem e, sobretudo, devido ao seu elevado número, merecem ser analisados, até porque decorrem da ineficácia do ataque inicial, pelo que não podem deixar de ser tidos em conta, se se quiser melhorar a eficiência das equipas de primeira intervenção e obter ganhos de eficácia no que respeita aos resultados da atuação dessas equipas.

Com efeito, das 68.298 ocorrências investigadas, em 26466 delas (quase 40\%), foram identificadas situações de reacendimento, números que não nos podem deixar indiferentes, uma vez que se os incêndios iniciais tivessem ficado efetivamente extintos, a maior parte destas ocorrências/reacendimentos não seria merecedora de qualquer referência.

Por outro lado, como os reacendimentos podem manifestar-se em qualquer uma das seis categorias codificadas, eles nada têm a ver com a causa inicial (que, aliás, apenas foi identificada em 4243 dessas situações, ou seja, em cerca de $15 \%$ dos reacendimentos), mas tão somente e apenas com a extinção mal consolidada dos focos iniciais.

Nestes casos valeria a pena averiguar se ela ficou a dever-se a uma saída precipitada dos meios, para fazer face a uma nova ocorrência que, entretanto, tenha eclodido ou, se, pelo contrário, resultou de um trabalho mal concluído, situação que, obviamente, terá de ser analisada, a fim de evitar a sua repetição.

Lamentavelmente, este tipo de análise, de verificação do que correu mal, raramente é realizada, o que leva a que não se aprenda com os erros do passado e, deste modo, se continuem a repetir, perpetuando-se, ao ponto de, por vezes, haver até tendência para quase os passar a regra. Veja-se o caso do uso exclusivo da água na consolidação dos rescaldos, e que em certos tipos de rescaldo é ineficaz, mas continua a resistir-se à sua utilização conjunta com as ferramentas manuais, a qual se tem revelado muito mais eficaz.

Subsistem, pois, alguns problemas de ordem operacional, no que respeita à fase de consolidação do rescaldo, que têm facilitado tão elevado número de reacendimentos. Pouco se fala do assunto, por razões óbvias, mas porque os reacendimentos ocorrem em grande número e, muitos deles, são responsáveis por grandes áreas ardidas, este assunto não pode deixar de, mais cedo ou mais tarde, ser devidamente abordado.

Como todos bem sabemos, decorrem de situações de má consolidação da fase de rescaldo, sobretudo quando as condições meteorológicas são favoráveis à ignição e as áreas envolventes apresentam elevada concentração de combustíveis, fatores que, em conjunto, contribuem para a rápida reativação/reacendimento de incêndios considerados extintos.

$\mathrm{O}$ ano de 2005 foi um ano particularmente crítico no que respeita às ignições ocorridas em todo o território português. Muitos dos fogachos supostamente extintos reacenderam e se transformaram em incêndios de grandes dimensões, não dando descanso às equipas de combate. Por vezes, em alguns deles, não houve condições para consolidar eficazmente os rescaldos, como se registou, por exemplo, no distrito de Leiria, onde "contabilizaram-se mais reacendimentos do que incêndios com mais de um hectare, por tanto, houve fogachos com segunda vida" (VIEIRA, 2006).

Em termos anuais, verifica-se que os reacendimentos assumem maior destaque no domínio dos fogachos do que em incêndios (Figura 9), o que resulta dos simples factos de, por um lado, todos os incêndios começarem por ser fogachos, pois só ganham dimensão quando não são extintos enquanto pequenos, e, por outro lado, porque o número de fogachos é maior do que o dos incêndios, pelo que é natural que o maior número de reacendimentos seja naqueles.

Curiosamente, em termos dos incêndios com causa investigada, nos primeiros anos, de 1996 a 1999, observou-se um decréscimo significativo do número de reacendimentos, passando de mais de 5000 para menos 


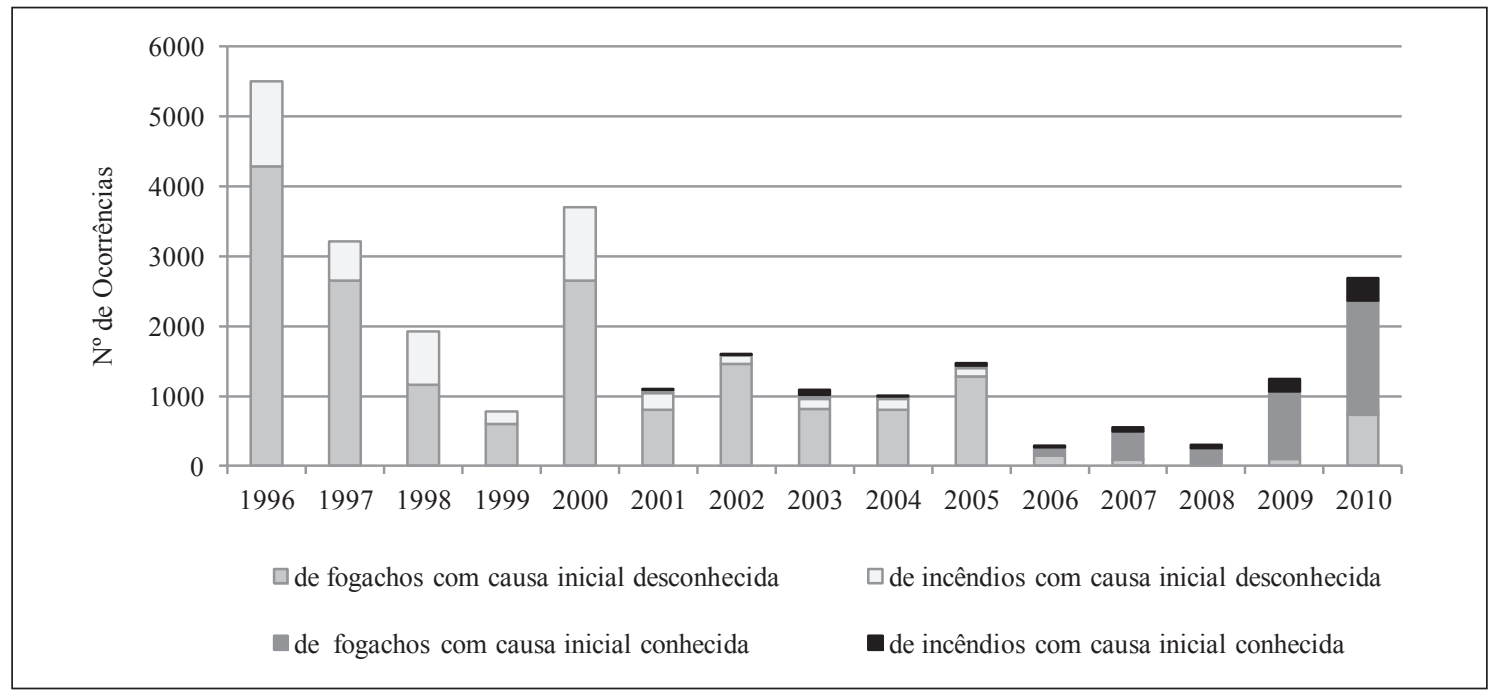

Figura 9

Distribuição anual dos reacendimentos em fogachos e em incêndios, com causa inicial conhecida ou desconhecida, investigados entre 1996 e 2010. Fonte: Dados estatísticos da Autoridade Florestal Nacional.

de 800 . 0 ano de 2000 voltou a ser anormal, com mais de 3700 reacendimentos, e a partir de 2001 até 2008 o número de reacendimentos investigados situou-se pelos 1000 , tendo voltado a aumentar substancialmente nos anos de 2009 e 2010, uma das razões que nos levou a dedicar algum espaço a esta análise, por poder ser um indicador preocupante.

Com efeito, como entre 2001 e 2008 se verificou que o valor dos reacendimentos se situou abaixo das 2000 ocorrências, com os anos de 2006 a 2008 a apresentarem os valores mais baixos dos 15 anos em estudo, poderia pensar-se que houve uma melhoria na eficácia das primeiras intervenções de combate aos incêndios florestais. Todavia, tendo em consideração que a percentagem de ocorrências investigadas durante a maior parte dos anos relativos a este período foi muitíssimo baixa (Figura 2), não é possível concluir que este decréscimo no número de reacendimentos resulte de um combate mais eficiente, em termos de primeira intervenção, pois também poderá decorrer da substancial redução do número de ocorrências investigadas, como aliás parecem comprovar os números relativos aos dois últimos anos considerados.

Voltando à codificação, além das causas antes descritas, associadas à conduta imprópria do ser humano para com os espaços com aptidão florestal, em quinto lugar surgem ainda causas humanas de natureza acidental e, só depois, em sexto lugar, aparecem as causas naturais. No final da tabela, em sétimo lugar, surgem as estruturais.
Sem pretendermos alongar-nos nos comentários inerentes a estas últimas, não podemos deixar de mencionar as naturais, associadas apenas a ignições provocadas por descargas atmosféricas, vulgarmente designadas por faíscas ou queda de raios, que embora não assumam, enquanto categoria de causa, uma grande representatividade, merecem referência por duas ou três ordens de razão.

A primeira será para realçar que se extrapolarmos para o universo do total das ocorrências o resultado da investigação das suas causas, como tem sido feito, mas ao contrário do que deverá fazer-se, verificamos que a percentagem dos incêndios naturais foi, neste período, inferior a $1 \%$. Como sabemos, não tem sido essa a informação veiculada, nem pela comunicação social nem pelos políticos, pelo que já é tempo de dar alguma seriedade ao tratamento da informação.

Por outro lado, estes números demonstram claramente que o problema dos incêndios florestais em Portugal está associado a causas humanas, o que significa que podem ser prevenidos.

Por último, as forças de combate devem estar particularmente atentas às ignições provocadas por raio, na medida que estas podem levar a situações de alguma complexidade, dado que as "trovoadas secas" características do verão, ao estarem associadas a instabilidade atmosférica e a temperaturas elevadas, muitas vezes provocam incêndios, uma vez que os raios, ao atingirem o solo, encontram uma cobertura vegetal ressequida que se incendeia com enorme facilidade. 
Além disso, a situação agrava-se pela quase simultaneidade da descarga de várias faíscas que, assim, podem desencadear diversos focos de incêndio relativamente próximos uns dos outros e quase ao mesmo tempo, o que conduz à dispersão dos meios de combate.

\subsection{Distribuição horária por categorias de causa}

Da análise realizada à distribuição das ocorrências por categorias de causa e por hora de início (Figura 10), observou-se que, na generalidade, a curva de evolução de cada uma das categorias de causa apresenta um comportamento muito semelhante, com tendência a registar um aumento do número de ocorrências, sensivelmente a partir das 10 horas da manhã, atingindo o máximo entre as $14 \mathrm{~h}$ e as 15 horas. Depois, decresce para valores mais baixos, até às $19 \mathrm{~h}$, seguindo-se uma ligeira subida das 20 às 21 horas, relacionada com um menor registo de ocorrências à hora do jantar, para voltar a diminuir até ao início da manhã, estabilizando entre as 5 e as 8 horas, altura em que volta a aumentar.

De notar a evolução das curvas do "Uso do Fogo" e do "Incendiarismo", que descrevem um comportamento muito semelhante, o que não deixa de ser curioso, com um clímax de ocorrências por volta da $15 \mathrm{~h}$.

Como é sabido, durante a noite a tendência é para que o número de ocorrências diminua, já que, normalmente, o período da madrugada é caracterizado por algum arrefecimento noturno que, além da descida da temperatura é acompanhado pelo aumento da humida- de relativa do ar, a qual contribui para a humidificação dos combustíveis, dificultando assim a ignição.

Numa análise mais detalhada à distribuição horária das diferentes causas de ocorrências, observou-se que as categorias Uso do fogo, Acidentais e Estruturais, apresentaram, no final da manhã, uma tendência para um aumento do número de ocorrências, especialmente, a categoria ligada ao uso indevido do fogo, atingindo um ponto máximo, entre $14 \mathrm{~h}$ e $16 \mathrm{~h}$, o que também sucedeu com as restantes categorias (Figura 11).

Quanto às categorias de Incendiarismo, Naturais e Indeterminadas, a distribuição horária é semelhante à anterior, observando-se um aumento do número de ocorrências a partir das $9 \mathrm{~h}$, aumentando tendencialmente e atingindo o seu clímax pelas 15h (Figura 12), acompanhando o aumento da insolação e da temperatura do ar.

Quando se analisou o comportamento dos reacendimentos (Figura 13), verificou-se que, em termos horários existe um comportamento semelhante aos anteriormente descritos, devido ao facto de, sensivelmente a partir das $7 \mathrm{~h}$, se verificar um certo aquecimento que com o passar das horas se intensifica à medida que a obliquidade dos raios solares vai diminuindo. Não deixa, por isso, de ser significativo que, entre as $12 \mathrm{~h} \mathrm{e}$ as $13 \mathrm{~h}$, se tenha registado, em média, um aumento de cerca de 30 reacendimentos, mantendo-se, depois, em valores elevados até às $15 \mathrm{~h}$, facto que também poderá estar relacionado com a hora de almoço.

No período da madrugada, a propensão é para que o número de reacendimentos seja pouco significati-

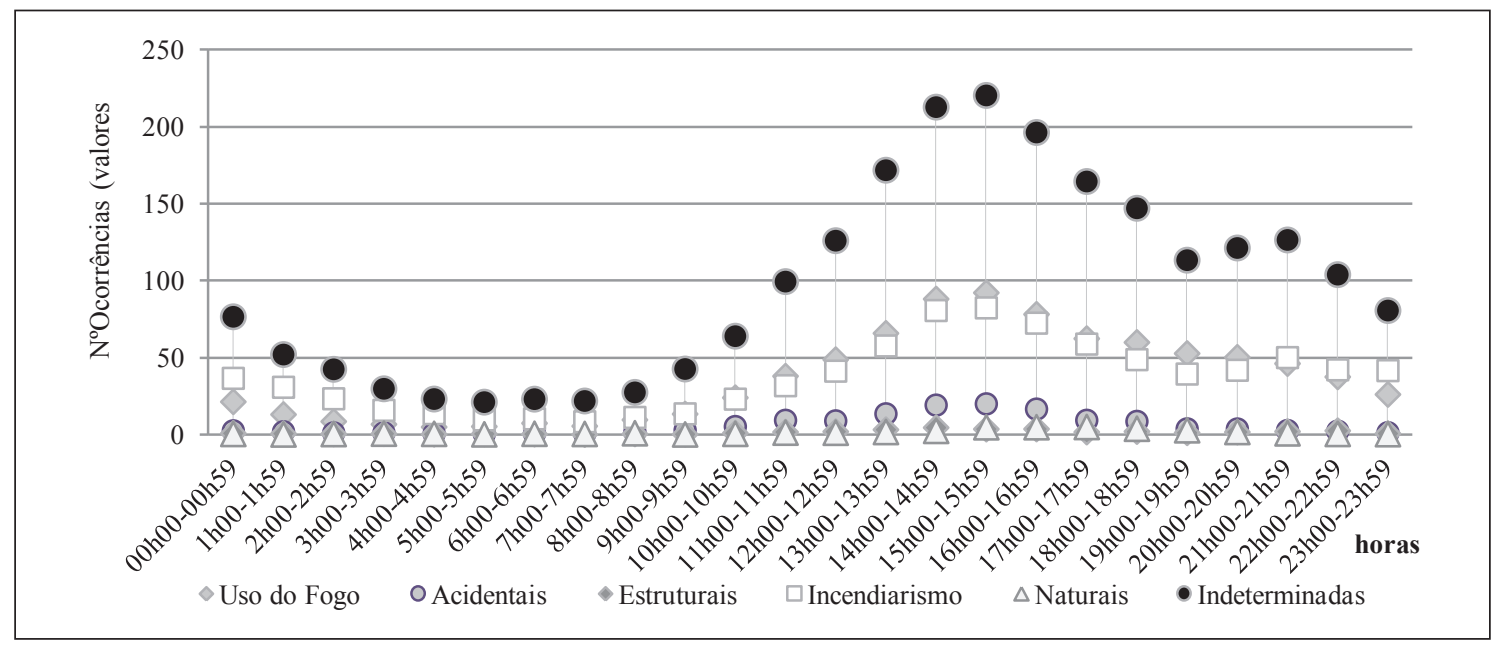

Figura 10

Distribuição média anual das ocorrências investigadas, por categorias de causa e por hora de início, entre 1996 e 2010.

Fonte: Dados estatísticos da Autoridade Florestal Nacional. 


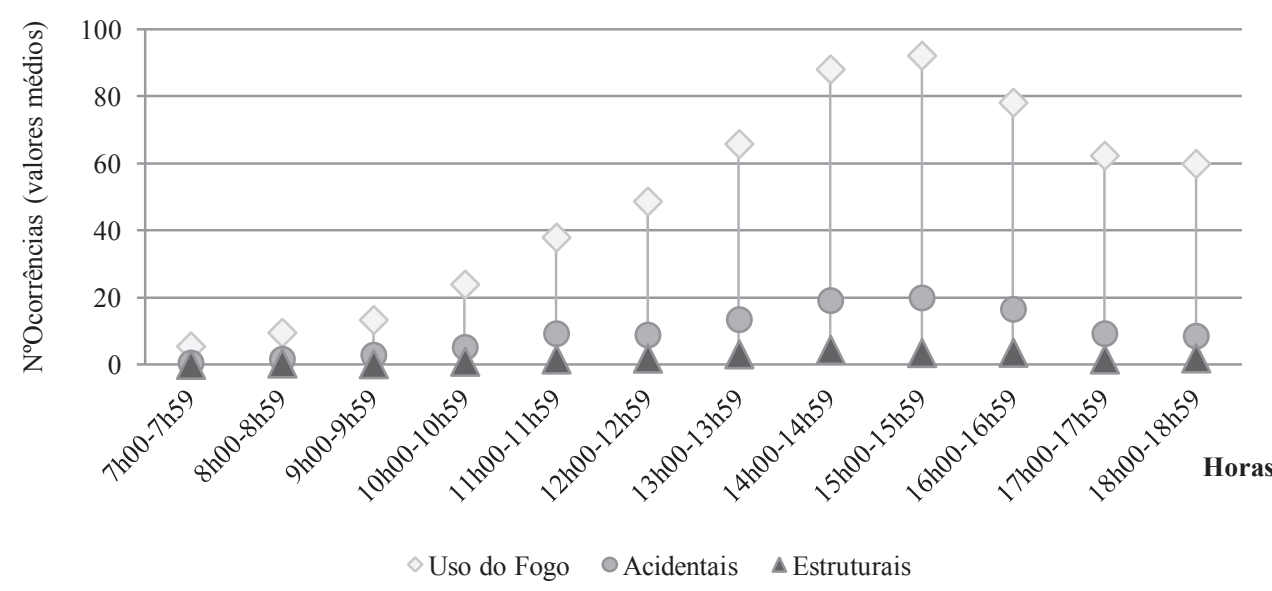

Figura 11

Distribuição horária da média anual de ocorrências investigadas, por categorias de Uso do Fogo, Acidentais e Estruturais, entre 1996 e 2010. Fonte: Dados estatísticos da Autoridade Florestal Nacional.

vo atendendo às condições atmosféricas que se verificam nessas horas, embora, na presença de vento e, caso o rescaldo não tenha sido bem consolidado, haja a probabilidade do incêndio se reacender.

\subsection{Repartição por subtipos}

A distribuição das causas por subtipos, entre 2001 e 2010, resulta do simples facto, como já foi mencionado, de somente ser feita referência aos subtipos a partir do ano de 2001, de acordo com a nova codificação e definição das categorias de causa da Autoridade Florestal Nacional (AFN).
Relativamente aos subtipos de Uso do Fogo, a partir do ano de 2007, cada um destes assume valores significativos, com destaque para o uso do fogo aplicado à Queima do Lixo, às Queimadas e Fogueiras, ao ato de Fumar e, sobretudo em 2010, às Chaminés (Figura 14).

No que respeita ao uso do fogo, no Lançamento de Foguetes observou-se uma certa manutenção dos valores, ao longo dos 10 anos em estudo, tendo sofrido apenas pequenas variações, o que em parte se poderá justificar pela forte tradição do lançamento de fogo-deartifício, sobretudo nas festas populares, mesmo ha-

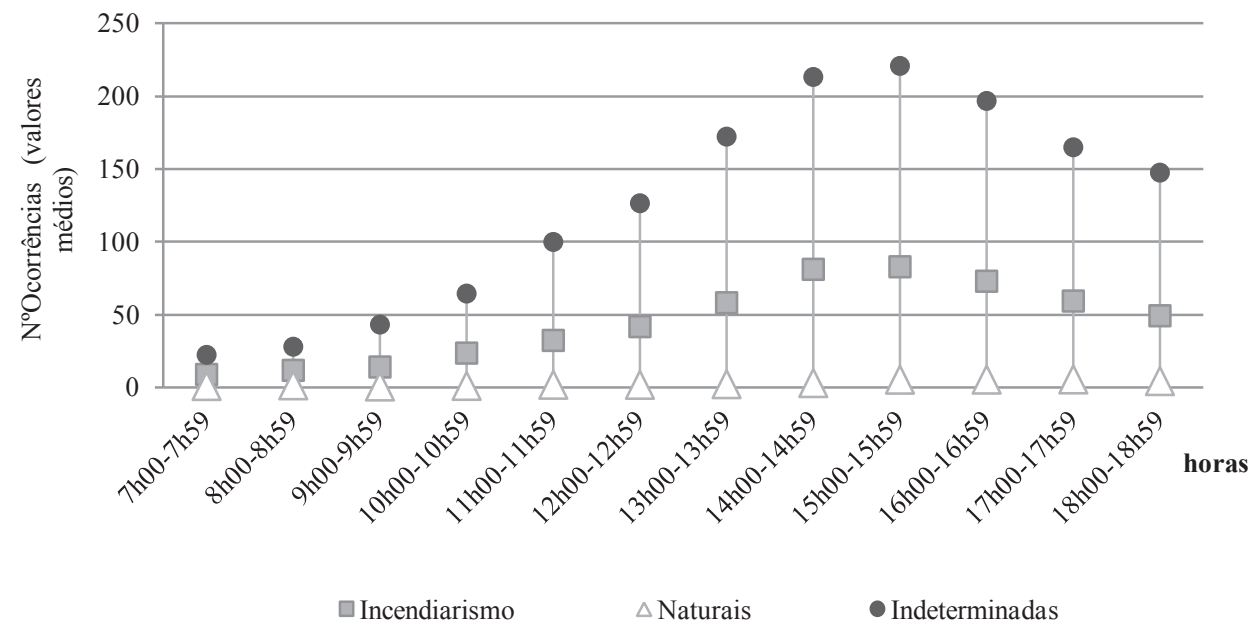

Figura 12

Distribuição horária da média anual de ocorrências investigadas, por categorias de Incendiarismo, Naturais e Indeterminadas, entre 1996 e 2010. Fonte: Dados estatísticos da Autoridade Florestal Nacional. 


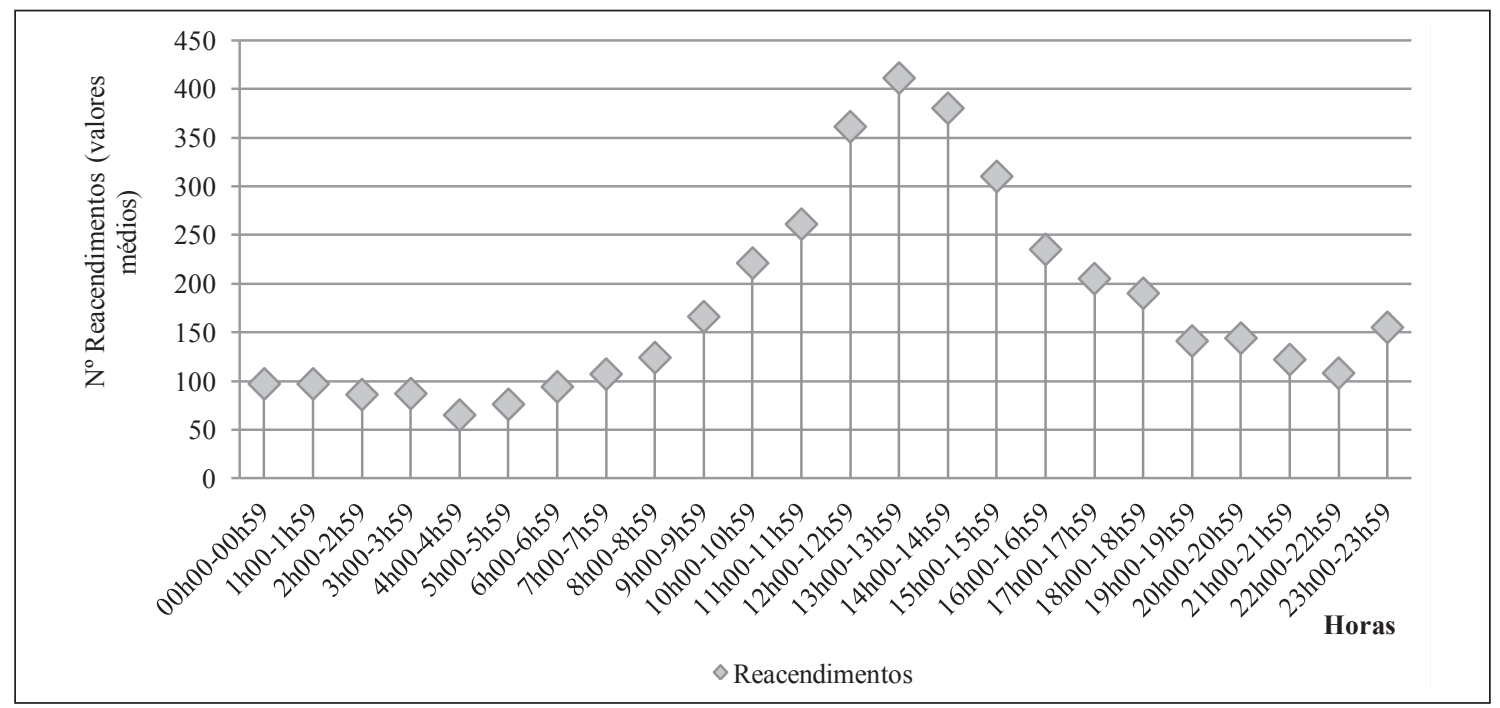

Figura 13

Distribuição horária da média anual de ocorrências em reacendimentos investigados, entre 1996 e 2010.

Fonte: Dados estatísticos da Autoridade Florestal Nacional.

vendo consciência de que esse lançamento pode dar início a incêndios.

Quanto à evolução anual dos subtipos das causas Acidentais verificou-se que desde o ano de 2002 tem havido um ligeiro acréscimo anual, ao nível dos três subtipos, com exceção do ano de 2007 , em que se verificou um aumento mais significativo, de cerca de $10 \%$ (Figura 15).

Quanto aos subtipos das causas Estruturais, entre 2001 e 2010 observou-se, no subtipo "Caça e vida selva- gem", uma quebra acentuada de 2005 para 2006 e, depois, um ligeiro aumento, pouco significativo, de 2006 para 2007, ano a partir do qual aumentou significativamente, e a partir de então os valores mantiveram-se mais ou menos constantes, o que pode permitir deduzir que este subtipo ganhou importância nos últimos anos, no contexto dos incêndios florestais no nosso país (Figura 16).

No que concerne à distribuição anual dos dois subtipos de Incendiarismo observou-se um acréscimo significativo desde 2007 nas situações imputáveis, com

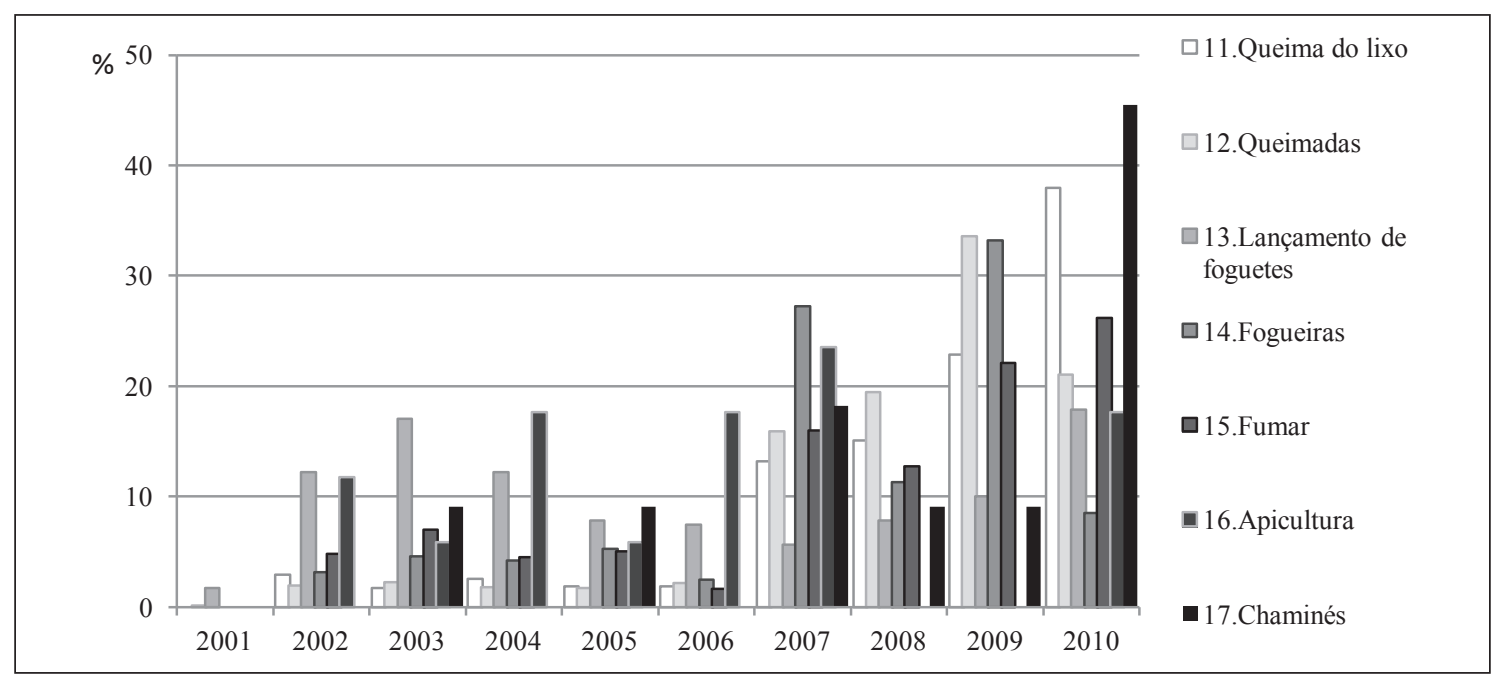

Figura 14

Distribuição anual dos incêndios investigados a nível Nacional, entre 2001 e 2010, em percentagem, por subtipos da causa Uso do Fogo.

Fonte: Dados estatísticos da Autoridade Florestal Nacional. 


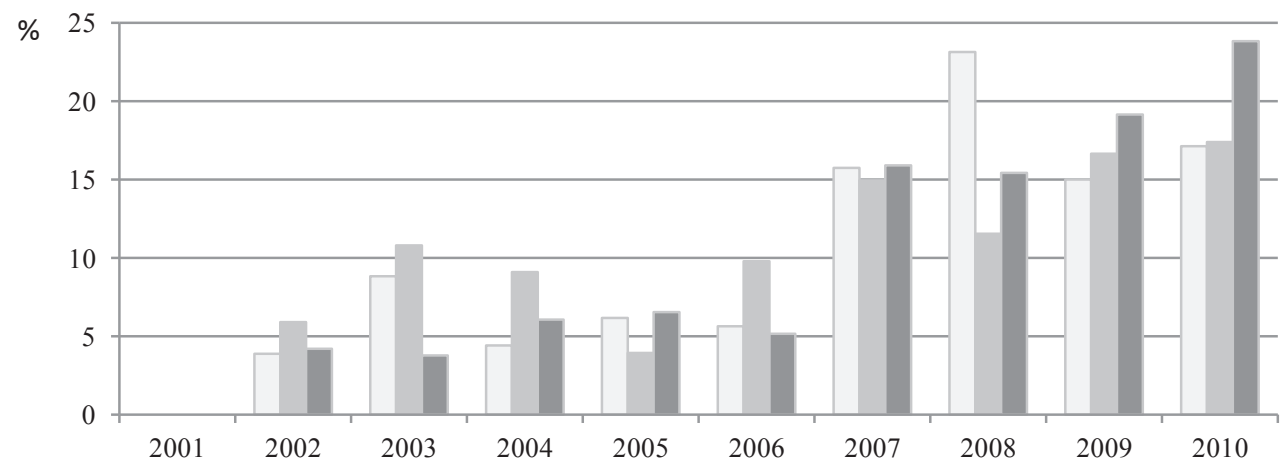

$\square$ 21.Transportes e Comunicações $\square$ 22.Maquinaria e Equipamento $\square$ 23.Outras causas acidentais

Figura 15

Distribuição anual dos Incêndios Florestais investigados a nível Nacional, entre 2001 e 2010, em percentagem, por subtipos de causas Acidentais.

Fonte: Dados estatísticos da Autoridade Florestal Nacional.

relevância para os anos de 2009 e 2010. No domínio das situações inimputáveis, as variações foram menores, embora com destaque dos anos de 2007 e 2008 (Figura 17).

Observa-se de novo, aquilo que já se verificou nos casos anteriores, ou seja, que na passagem de 2006 para 2007 existe, de facto, um forte aumento do número das ocorrências, independentemente da categoria de causa em estudo, o que pode resultar, apenas, de se ter alargado o universo de amostragem, em função da maior percentagem das ocorrências investigadas, a partir desse ano (Figura 2).
Quanto à distribuição anual do único subtipo de causa Natural, que corresponde aos incêndios florestais originados por raios ou faíscas, provenientes de descargas elétricas provocadas por trovoadas, verificou-se que estas apresentam uma grande variabilidade. Também, como no caso anterior, e porventura por razões análogas às apontadas, o período até 2005 revela-se claramente diferente do seguinte, com início em 2006. Com efeito, cerca de $80 \%$ dos incêndios provocados por raio foram registados neste último período, no qual todos os anos registaram valores superiores a $5 \%$ do total de ocorrências. Pelo contrário, no período anterior,

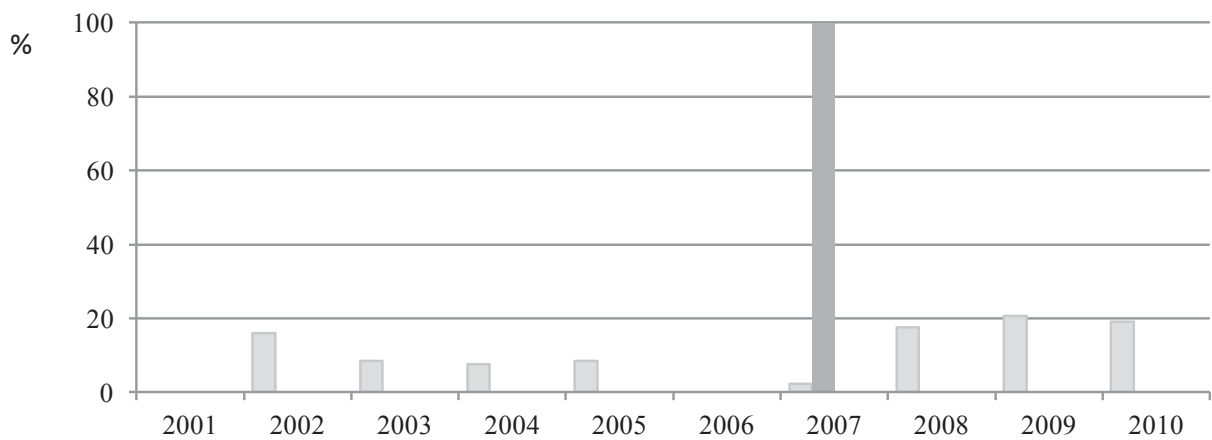

$\square$ 31.Caça e vida selvagem

$\square$ 33.Uso do solo

—37.Defesa contra incêndios

-38.Outras causas estruturais

Figura 16

Distribuição anual, em percentagem, dos incêndios investigados a nível Nacional, entre 2001 e 2010, por subtipos de Causas Estruturais.

Fonte: Dados estatísticos da Autoridade Florestal Nacional. 


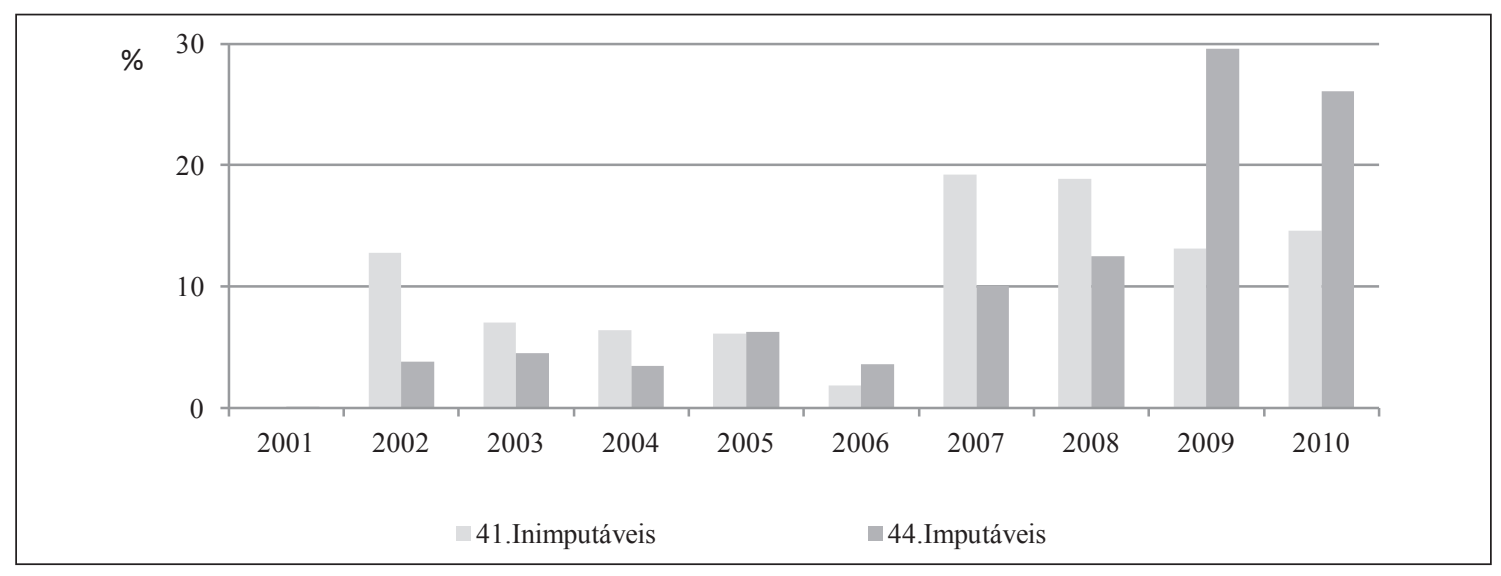

Figura 17

Distribuição anual, em percentagem, dos incêndios florestais investigados a nível Nacional, entre 2001 e 2010 , por subtipos da causa Incendiarismo. Fonte: Dados estatísticos da Autoridade Florestal Nacional.

apenas o ano de 2003 registou um valor superior a $5 \%$ e, como recordamos, foi o ano em que Portugal registou maior quantidade de incêndios com origem natural, inversamente ao que a investigação das causas aponta, uma vez que os anos com maior incidência foram os de 2009 e 2010 (Figura 18).

Em relação aos incêndios florestais investigados em que não foi possível determinar a verdadeira origem, verificou-se que a tendência foi sobretudo para o aumento do número de ocorrências catalogadas como Indeterminadas, sobretudo, e uma vez mais, a partir do ano de 2006. Estes anos registaram valores entre 15 e $20 \%$ das ocorrências, com exceção do próprio ano de 2006, em que foi inferior a 10\%, e, também, de 2010, que atingiu o máximo, próximo de $30 \%$. Em contrapartida, até 2005, o valor anual situou-se sempre abaixo de 5\% (Figura 19).
Para concluir esta análise, falta referir todas as ocorrências em que não foi mencionado nenhum subtipo de categorias de causa.

Uma simples observação permite mostrar claramente três períodos distintos ao longo do quindénio. 0 primeiro deles, corresponde aos primeiros quatro anos, de 1996 a 1999, com valores anuais situados ente 10 e $15 \%$ do efetivo total, atendendo a que a codificação em uso nestes anos não apresentava qualquer tipo de referência aos subtipos das categorias, por considerar apenas as causas: Negligente, Intencional, Naturais e Desconhecidas.

Seguiu-se um segundo período, entre 2000 e 2006, com valores anuais inferiores a $5 \%$ do total (Figura 20). Com efeito, o ano 2000 correspondeu a uma significativa redução, com menos de metade do valor do ano anterior, situação que se repete em 2002, com uma

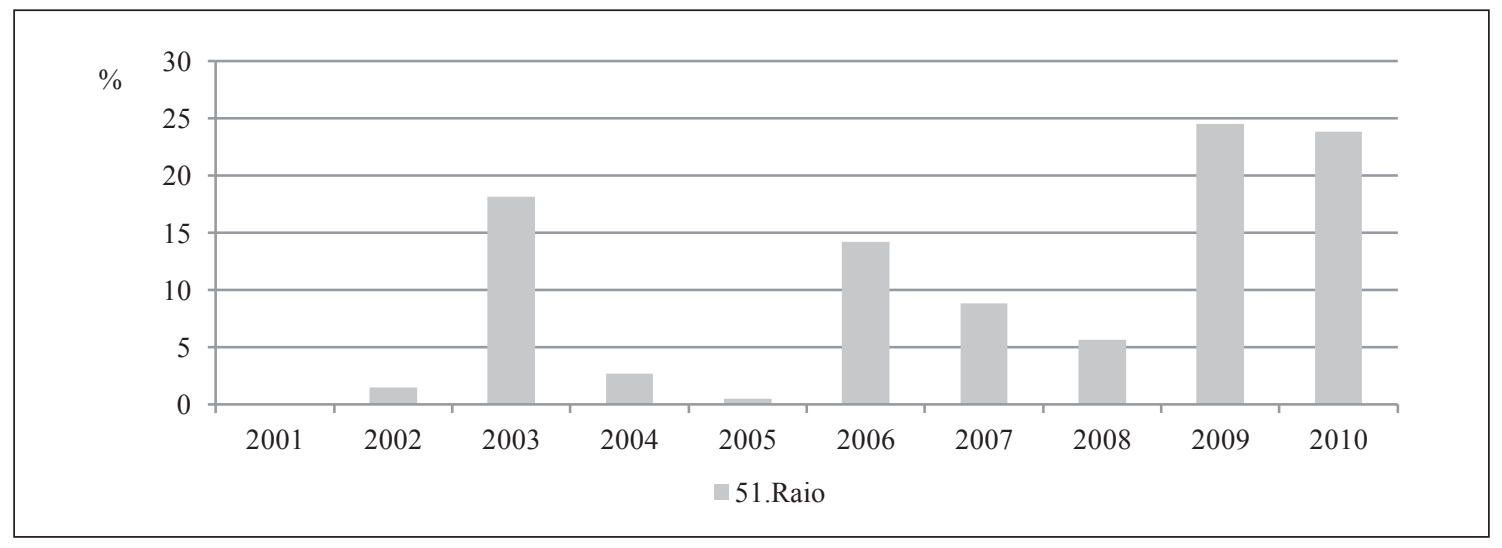

Figura 18

Distribuição anual, em percentagem, dos incêndios florestais investigados, a nível Nacional, entre 2001 e 2010, com origem em causa Natural.

Fonte: Dados estatísticos da Autoridade Florestal Nacional. 


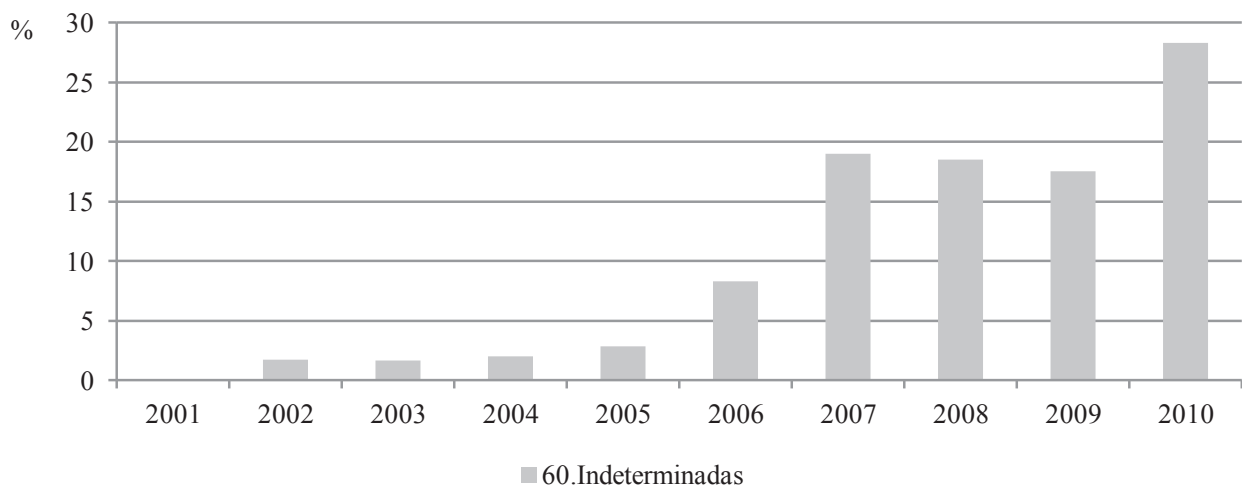

Figura 19

Distribuição anual, em percentagem, do subtipo causa Indeterminada, dos incêndios investigados a nível Nacional, entre 2001 e 2010. Fonte: Dados estatísticos da Autoridade Florestal Nacional.

diminuição para valores irrisórios, e se mantém nos anos seguinte, com um ligeiro aumento em 2005 e um acréscimo bastante mais substancial em 2006, que corresponde ao último ano deste conjunto e marca a viragem para o terceiro e último período, em que os valores anuais se situaram acima de $5 \%$.

Aliás, esta viragem em 2006, já descrita nos subtipos anteriores, parece traduzir, cada vez mais, a crescente dificuldade, sentida por parte das entidades oficiais competentes, em definir os vários subtipos, tornando-se substancialmente mais simples mencionar apenas a referência às respetivas categorias.

No entanto, apesar deste aumento nos últimos anos, não se pode deixar de realçar que estamos a comparar três realidades diferentes, correspondentes a cada um destes períodos, em que a percentagem de incêndios investigados em cada um deles também foi bastante diferente (Figura 2).

\section{Conclusão}

A problemática desenvolvida em torno das origens dos incêndios florestais em Portugal apresenta alguma complexidade na medida em que assenta, basicamente em dois tipos de variáveis. Por um lado, algumas delas decorrem das características estruturais do país, que apesar de não terem sido tratadas, são conhecidas: (1) a distribuição dos povoamentos florestais e dos matos em manchas contínuas, das mesmas espécies, com elevado grau de inflamabilidade, (2) a falta gestão na maior parte das matas e florestas, (3) o absentismo da

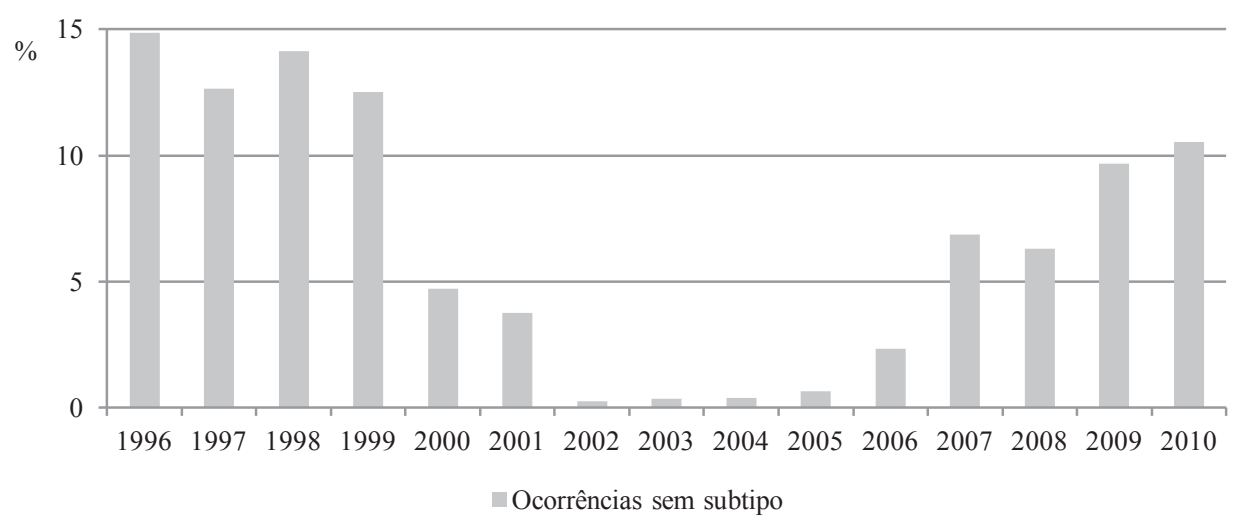

Figura 20

Distribuição anual, em percentagem, dos incêndios florestais investigados entre 1996 e 2010, a que não foi atribuído nenhum subtipo de causa. Fonte: Dados estatísticos da Autoridade Florestal Nacional. 
generalidade dos proprietários florestais, (4) a desestruturação do mundo rural, (5) o uso do fogo de tradição ancestral, como ferramenta de manjo florestal e para renovação de pastagens, etc.

Por outro lado, as relacionadas com as fontes de ignição, propriamente ditas, que como ficou demonstrado, são quase exclusivamente de origem humana, quer seja por ação voluntária, isto é, por ato intencional, quer seja, de forma negligente, por desleixo ou por descuido, onde se incluem os reacendimentos, por deficiente consolidação das ações de rescaldo.

Neste sentido, se do ponto de vista tático, o problema do combate aos incêndios poderá parecer resolver-se com a adequação da dotação e da disposição dos meios/recursos no território em função do respetivo risco de incêndio, resultante do número de ocorrências e da área ardida, o tempo não permite confirmar que seja essa a solução, não só porque não existe essa adequação dos recursos ao risco, mas também porque é necessário trabalhar as causas dos incêndios. Ora, se as causas estruturais se poderão resolver com prevenção, já a resolução das causas humanas vai muito além da prevenção.

O primeiro passo já foi dado com o reforço da investigação de causas. É necessário aumentar este esforço e, em simultâneo, afinar os procedimentos, de modo a não só reduzir o número de causas indeterminadas, mas também para que, cada vez mais, a investigação possa produzir melhores e mais resultados. Estamos firmemente convictos de que a redução do número de ocorrências passa, em primeiro lugar, pelo reforço da componente investigação das causas de incêndio.

Torna-se, ainda, necessário apostar em campanhas de sensibilização especialmente preparadas e dirigidas para os públicos-alvo específicos que, através do uso do fogo, sejam causadores involuntários de incêndios florestais: agricultores, apicultores, pastores, operários florestais ou outros que, pontualmente, trabalhem em espaços florestais.

Por sua vez, os incêndios com origem dolosa deverão ser punidos adequadamente.

Por último, os reacendimentos podem resolver-se com mais formação dos bombeiros, aliás, essencial para melhorar a eficácia do combate.

De facto, o investimento em conhecimento sobre a floresta, o combate aos incêndios florestais, a reabilitação e recuperação das áreas ardidas é, com certeza, o que tarda mais tempo, mas não há dúvida que é o de melhores efeitos e aquele que permite apresentar melhores resultados. Só será necessário aplicá-lo!

\section{Bibliografia}

AleXAndre, José Alberto (1998) - Incêndios e ordenamento florestal em Portugal, Instituto de Estudos Geográficos, Universidade de Coimbra, p. 198.

Autoridade Florestal Nacional (2006) Plano Nacional de Defesa da Floresta Contra Incêndios (PNDFCI), Diário da República n. ${ }^{\circ}$ 102, I-B Série, de 2006.05.26, disponível: http:// www.afn.min-agricultura.pt/portal/dudf/plano

Autoridade Florestal Nacional (s/d) - Codificação e definição das categorias de causas, disponível em: http://www.afn. min-agricultura.pt/portal/dudf/Resource /pdf/ estatisticas/dgrf-codificacao-causas.pdf

Bento-Gonçalves, A. J.; Lourenço, L. e Silva, J. (2007) - "Manifestação do risco de incêndio florestal, causas e investigação criminal”, Territorium, n. ${ }^{\circ} 14$, Coimbra, pp. 81-87.

Carvalho, Josefa e Lopes, Pedro (2001) - "Classificação de Incêndios Florestais, Manual de utilizador", DirecçãoGeral das Florestas, Lisboa, $34 \mathrm{p}$.

CorreIA, Sérgio (1992) - "Projeto de determinação das causas dos incêndios", DGF Informação, Direcção-Geral das Florestas, Lisboa, pp. 17-19.

CorreIA, Sérgio (1994) - "Determinação das causas de incêndios florestais. Metodologia", Atas do II EPRIF, Encontro Pedagógico sobre Incêndios Florestais, Coimbra, pp. 141-151.

CRUZ, Miguel (2003) - Relatório final dos incêndios florestais em 2002, Divisão de Proteção e Conservação Florestal, Direção Geral das Florestas, Lisboa, 43 p.

Direção de Unidade de DefeSA da Floresta (2009) - Relatório das áreas ardidas e ocorrências em 2008, Autoridade Florestal Nacional, Lisboa, $20 \mathrm{p}$.

Direção de UnidAde de Defesa da FloResta (2010) - Relatório anual de áreas ardidas e ocorrências 2009, Autoridade Florestal Nacional, Lisboa, $33 \mathrm{p}$.

Direção Unidade de Defesa da Floresta (2011) - Relatório anual de áreas ardidas e ocorrências 2010, Autoridade Florestal Nacional, Lisboa, $33 \mathrm{p}$.

Divisão de Defesa da Floresta Contra Incêndios (2004) - Relatório Provisório dos incêndios florestais de 2004, Direção Geral dos Recursos Florestais, Lisboa, 12 p.

Divisão de Defesa da Floresta Contra Incêndios (2006) - Relatório dos incêndios florestais de 2005, Direção Geral dos Recursos Florestais, Lisboa, 28 p.

Divisão de DefESA dA FloRESTA Contra IncÊndios (2007) - Relatório Final dos incêndios florestais de 2006, Direção Geral dos Recursos Florestais, Lisboa, $36 \mathrm{p}$. 
Divisão de Defesa da Floresta Contra Incêndios (2008) - Relatório Final dos incêndios florestais de 2007, Direção Geral dos Recursos Florestais, Lisboa, $44 \mathrm{p}$.

Divisão de Proteção e Conservação Florestal (2002) - Relatório Provisório dos incêndios florestais de 2001, Direção Geral das Florestas, Lisboa, 13 p.

Divisão de Proteção e Conservação Florestal (2003) - Relatório Provisório dos incêndios florestais de 2003, Direção Geral das Florestas, Lisboa, $13 \mathrm{p}$.

Galante, Miguel (2003) - Corpo Nacional da Guarda Florestal. Determinação das causas dos incêndios florestais em 2002 (Resumo técnico). Direcção-Geral das Florestas, Lisboa, 25 p.

Galante, Miguel (2005) - "As causas dos incêndios florestais em Portugal continental", Atas do $5^{\circ}$ Congresso Florestal Nacional, Viseu, 16 a 19 Maio, pp. 1-12.

Lourenço, Luciano (2007) - "Incêndios Florestais de 2003 e 2005. Tão perto no tempo e já tão longe na memória." In
Lourenço, Luciano (coord.) - Riscos Ambientais $e$ Formação de Professores, Núcleo de Investigação Científica de Incêndios Florestais da Faculdade de Letras da Universidade de Coimbra, Coimbra, pp. 19-91.

Lourenço, Luciano; Serra, Gouveia; Mota, Lucília; Paúl, José; Correia, Sérgio; Parola, José e Reis, José (2001) - Manual de Combate a Incêndios Florestais para Equipas de Primeira Intervenção, Escola Nacional de Bombeiros, Sintra, $208 \mathrm{p}$.

Pugnet, Lilian; Lourenço, Luciano e Rocha, João (2010) "L'ignition des feux de forêt par l'action de la foudre au Portugal de 1996 à 2008", Territorium, n 17, Coimbra, pp. 57-70.

Rebelo, Fernando (2003) - Riscos naturais e ação antrópica estudos e reflexões, Imprensa da Universidade, Coimbra, 286 p. ( $2^{\mathrm{a}}$ edição revista e aumentada).

VIEIRA, Pedro A. (2006) - Portugal: o vermelho e o negro, Dom Quixote, $2^{\text {a }}$ edição, 469 p.. 